\title{
Convergent functional genomics of anxiety disorders: translational identification of genes, biomarkers, pathways and mechanisms
}

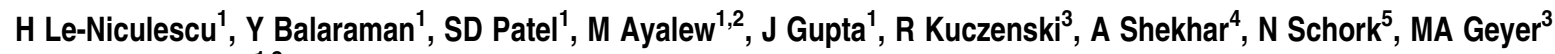 \\ and AB Niculescu, ${ }^{1,2}$
}

\begin{abstract}
Anxiety disorders are prevalent and disabling yet understudied from a genetic standpoint, compared with other major psychiatric disorders such as bipolar disorder and schizophrenia. The fact that they are more common, diverse and perceived as embedded in normal life may explain this relative oversight. In addition, as for other psychiatric disorders, there are technical challenges related to the identification and validation of candidate genes and peripheral biomarkers. Human studies, particularly genetic ones, are susceptible to the issue of being underpowered, because of genetic heterogeneity, the effect of variable environmental exposure on gene expression, and difficulty of accrual of large, well phenotyped cohorts. Animal model gene expression studies, in a genetically homogeneous and experimentally tractable setting, can avoid artifacts and provide sensitivity of detection. Subsequent translational integration of the animal model datasets with human genetic and gene expression datasets can ensure cross-validatory power and specificity for illness. We have used a pharmacogenomic mouse model (involving treatments with an anxiogenic drug-yohimbine, and an anti-anxiety drug-diazepam) as a discovery engine for identification of anxiety candidate genes as well as potential blood biomarkers. Gene expression changes in key brain regions for anxiety (prefrontal cortex, amygdala and hippocampus) and blood were analyzed using a convergent functional genomics (CFG) approach, which integrates our new data with published human and animal model data, as a translational strategy of cross-matching and prioritizing findings. Our work identifies top candidate genes (such as FOS, GABBR1, NR4A2, DRD1, ADORA2A, QKI, RGS2, PTGDS, HSPA1B, DYNLL2, CCKBR and DBP), brain-blood biomarkers (such as FOS, QKI and HSPA1B), pathways (such as CAMP signaling) and mechanisms for anxiety disorders-notably signal transduction and reactivity to environment, with a prominent role for the hippocampus. Overall, this work complements our previous similar work (on bipolar mood disorders and schizophrenia) conducted over the last decade. It concludes our programmatic first pass mapping of the genomic landscape of the triad of major psychiatric disorder domains using CFG, and permitted us to uncover the significant genetic overlap between anxiety and these other major psychiatric disorders, notably the under-appreciated overlap with schizophrenia. PDE10A, TAC1 and other genes uncovered by our work provide a molecular basis for the frequently observed clinical co-morbidity and interdependence between anxiety and other major psychiatric disorders, and suggest schizo-anxiety as a possible new nosological domain.
\end{abstract}

Translational Psychiatry (2011) 1, e9; doi:10.1038/tp.2011.9; published online 24 May 2011

\section{Introduction}

'Worry is a thin stream of fear trickling through the mind. If encouraged, it cuts a channel into which all other thoughts are drained.

\section{-Arthur Somers Roche}

Anxiety disorders are prevalent and disabling. Approximately 30 million people are affected with anxiety disorders in United States ${ }^{1,2}$ and the 12-month prevalence rate is estimated to be $18.1 \% .^{3}$ Anxiety disorders, under DSM classification, include generalized anxiety disorder (GAD), panic disorder, specific phobias, post-traumatic stress disorder (PTSD) and obsessive-compulsive disorder (OCD).
They can be grouped into those without an obvious external trigger (GAD, panic disorder), those with an obvious external trigger (PTSD, phobias) and those that are more of a mixed picture, like OCD. Anxiety disorders are often co-morbid with other psychiatric disorders such as depression, bipolar disorder, schizophrenia and substance abuse.4,5 Phenomenologicaly, anxiety disorders seem to have in common an increased reactivity to the environment, driven by uncertainty and fear of perceived threats. ${ }^{6}$ Stress is a common trigger and/or exacerbator.

Despite their prevalence and clinical impact, anxiety disorders are understudied from a genetic standpoint, compared with other major psychiatric disorders. Twin, adoption and familial studies have suggested a role for

\footnotetext{
${ }^{1}$ Department of Psychiatry, Indiana University School of Medicine, Indianapolis, IN, USA; ${ }^{2}$ Indianapolis VA Medical Center, Indianapolis, IN, USA; ${ }^{3}$ Department of Psychiatry, University of California at San Diego, La Jolla, CA, USA; ${ }^{4}$ Indiana Clinical Translational Science Institute, Indianapolis, IN, USA and ${ }^{5}$ Scripps Translational Science Institute, La Jolla, CA, USA

Correspondence: Professor AB Niculescu, Department of Psychiatry, Indiana University School of Medicine, 791 Union Drive, Indianapolis, IN 46202, USA.

E-mail: anicules@iupui.edu

Keywords: anxiety; biomarkers; blood; brain; genes; microarray

Received 1 March 2011; accepted 9 April 2011
} 
heritability in anxiety disorders. ${ }^{7,8}$ Human genetic linkage studies have identified some susceptibility loci. ${ }^{9-11}$ Genetic association studies have identified polymorphisms in genes such as corticotropin-releasing hormone $(\mathrm{CRH}),{ }^{12}$ glutamate transporter (SLC1A1), ${ }^{13}$ adenosine A2a receptor (ADORA2A), ${ }^{14}$ regulator of G-protein signaling 2 (RGS2), ${ }^{15,16}$ delta-aminolevulinate dehydratase (ALAD), ${ }^{17}$ dynein light chain 2 (DYNLL2) ${ }^{17}$ and others as possibly involved in anxiety disorders, but with limited reproducibility. There are few published human postmortem brain gene expression studies to date on anxiety and related disorders. ${ }^{18,19}$

To overcome this suboptimal state of affairs, we employed a comprehensive convergent functional genomics $(C F G)^{20-23}$ approach as a way of identifying and prioritizing candidate genes and blood biomarkers for anxiety disorders, as we did in our previous work on bipolar disorder, ${ }^{24-28}$ schizophrenia ${ }^{29,30}$ and alcoholism. ${ }^{31}$ As a first step, we used drug effects on gene expression in mice in key brain regions for anxiety (prefrontal cortex (PFC), amygdala (AMY) and hippocampus (HIP)), ${ }^{32}$ as well as blood (BLD), as a way to tag genes that may have pathophysiological relevance. We then cross-matched and integrated that gene-level data with multiple other lines of evidence (genetic and gene expression) from human studies and other animal model studies (Figure 1).

For our mouse brain and blood gene expression studies, we used an agonist drug, which induces symptoms of anxiety (yohimbine), ${ }^{33-35}$ and a gold standard antagonist drug, which is used to treat anxiety disorders (diazepam) ${ }^{36,37}$ (Figure 1). From the range of doses of the drugs that had been reported in the literature to have our desired behavioral effects, we chose doses at the low end of the range, to minimize potential supraphysiological dosing artifacts and side-effects. We also employed a behavioral readout to make sure the drugs were absorbed and doing what they were supposed to do (Figure 2).

Changes in gene expression in response to each of the two drugs, yohimbine and diazepam, would be of interest in and of themselves, in terms of candidate gene generation and CFG. However, not all genes that show changes in expression in response to either of the drugs are necessarily germane to the pathophysiology of anxiety and related disorders. It is likely that some of the gene expression changes have to do a

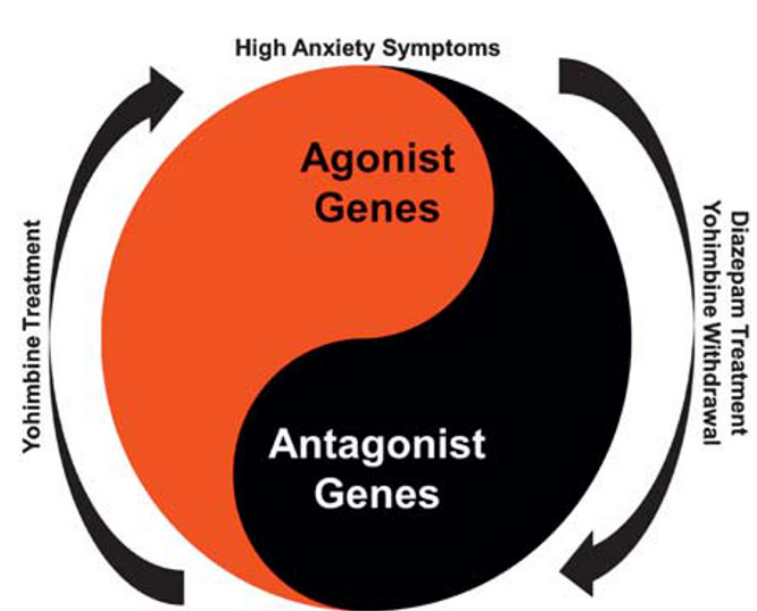

C b

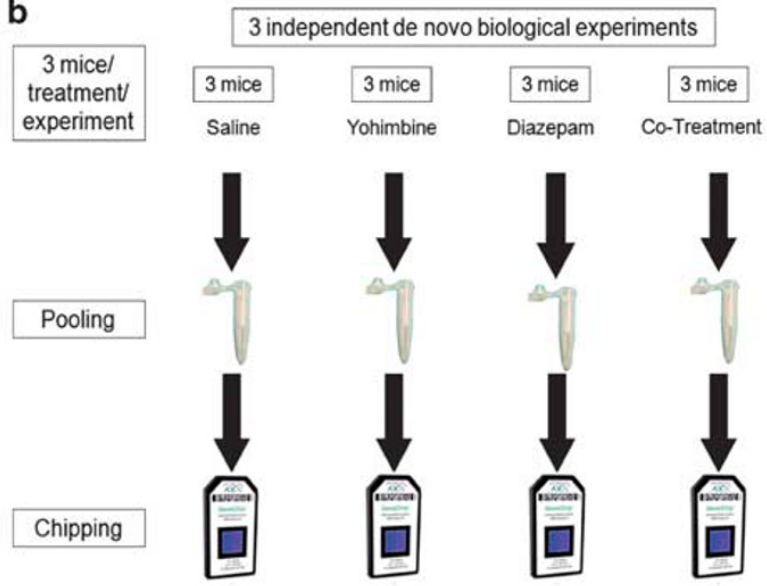

d

\section{Convergent Functional Genomics}

Multiple Independent Lines of Evidence

For Bayesian Cross-Validation of Pharmacogenomic Data

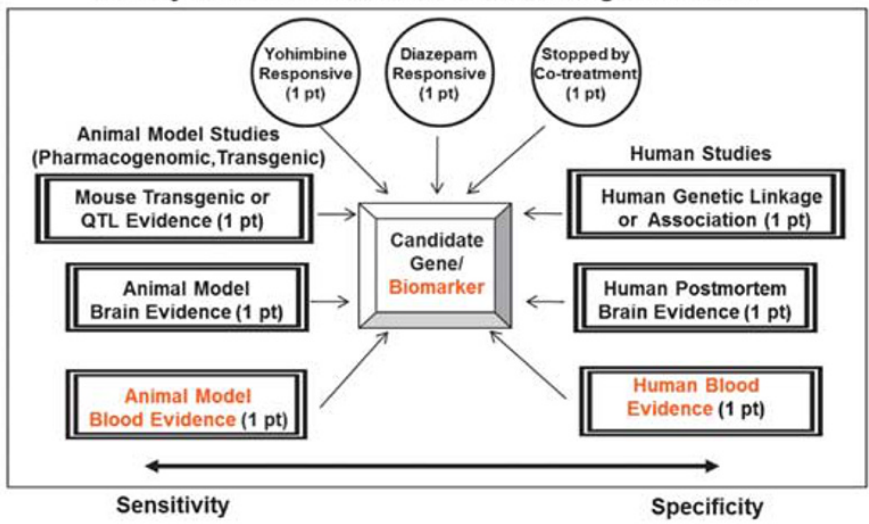

I. Genes Changed in Yohimbine and Diazepam, but not in Co-Treatment experiments

II. Genes Changed in both Yohimbine and Diazepam experiments

III. Genes Changed in either Yohimbine or Diazepam, but not in CoTreatment experiments

IV. Genes Changed in either Yohimbine or Diazepam experiments

Figure 1 Design of experiments and data analysis. (a) Pharmacological treatment paradigm. (b) Experimental design. (c) Venn diagram categorizing genes changed by the various drug treatments, and their classification into categories I, II, III and IV. (d) Multiple converging independent internal and external lines of evidence for crossvalidation and prioritization of findings. 


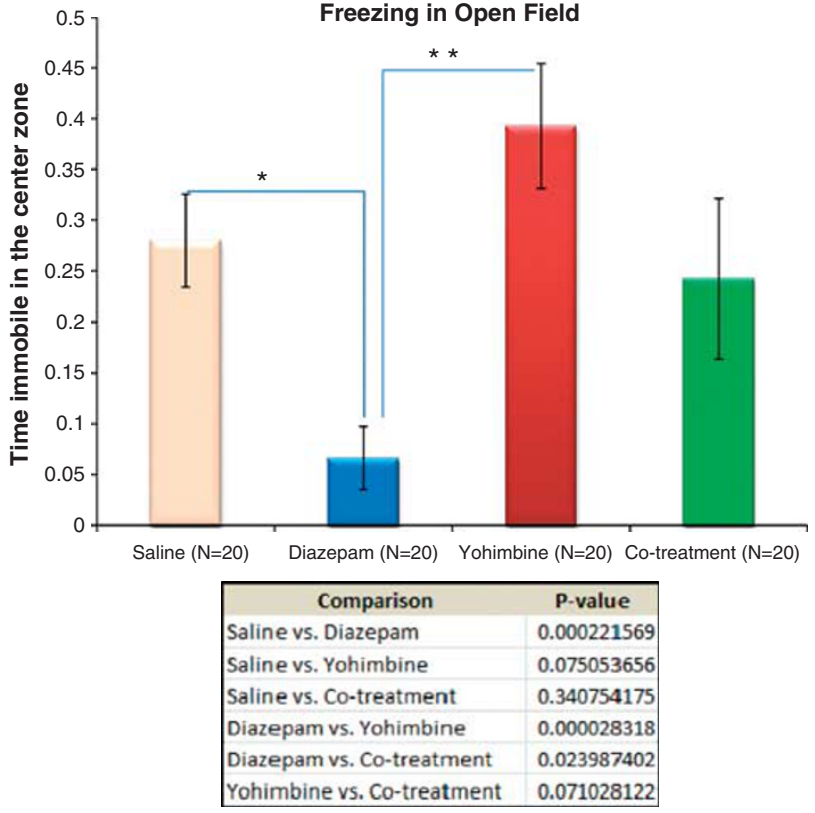

Figure 2 Behavioral correlates of diazepam and yohimbine treatment-time immobile in center zone. Analysis of mouse open field video-tracking behavioral phenotype data from 15 to 30 min after drug injections. Ratio of resting time in the center zone vs total time spent in the center zone. This measure reflects freezing behavior, an anxiety-driven phenomenon. Yohimbine increases freezing, diazepam reduces it, and co-treatment does not have an effect. One-tail $t$-tests are depicted. ${ }^{*}$ ) Statistically significant. The difference between diazepam and yohimbine is highly statistically significant $\left(^{* *}\right)$.

with other effects of the drugs, particularly their individual side-effects. We reasoned, first, that genes that change in expression in response to both drugs are more likely to be involved in the core pathophysiology we are modeling, and are higher probability candidate genes. Second, cotreatment with the two drugs, one an anxiogenic, and the other one an anxiolytic, could arguably show interference effects, and some of the genes that would be changed by single drug treatment would be 'nipped in the bud' and show no changes in expression in response to co-treatment. Those genes would also be deemed higher probability candidate genes than the genes that still change during co-treatment

As external cross-validators, for each gene changed in expression in our pharmacogenomics studies, we used six independent lines of evidence in our CFG analyses (Figure 1d). First, we assessed if there was any published genetic evidence-human genetic evidence of association with anxiety, or at least if it mapped to a linkage locus that had been implicated in anxiety disorders. We also looked at mouse transgenic or quantitative trait loci (QTL) studies relevant to anxiety. Second, we assessed if there was any published gene expression evidence in brain or blood in anxiety disorders, from human studies and, more broadly, from other animal models of anxiety. ${ }^{38}$ These external lines of evidence suffer from the obvious drawback of being constrained by what has been published so far, limiting novelty, and to the inherent biases and limitations of those particular lines of work.
According to Bayesian theory, an optimal estimate results from combining previous information with new evidence. Although we cannot exclude that some of the candidate genes we have identified are false positives because of potential biological or technical limitations of the methodology and approach we employed, the higher the number of independent lines of evidence (i.e. the higher the CFG score), the lower the likelihood of that being the case. The CFG scoring is arguably a reasonable compromise between specificity and sensitivity, between focus and broadness.

Our approach identifies and prioritizes an extensive series of candidate genes, some of which have already been reported using various related treatments or paradigms, as well as many others which are novel. Moreover, the coalescence of the candidate genes into pathways and mechanisms is of particular importance and opens new directions. Finally, we compared our results with our previous similar work in bipolar disorder, ${ }^{25,26}$ schizophrenia ${ }^{29}$ and alcoholism, ${ }^{31}$ and were able to analyze the significant genetic overlap between anxiety and these other disorders, providing a molecular basis for the frequently observed clinical co-morbidity.

\section{Materials and methods}

Yohimbine and diazepam treatments. All experiments were performed with male C57/BL6 mice, 8-12 weeks of age, obtained from Jackson Laboratories (Bar Harbor, ME, USA), and acclimated for at least 2 weeks in our animal facility (Indiana University School of Medicine LARC) on reverse light cycle (1000 to 2200 hours) before any experimental manipulation. All experiments were conducted at the same time of day-between 1400 and 1600 hours. Mice were treated by intraperitoneal injection with singledose of yohimbine $\left(1 \mathrm{mg} \mathrm{kg}^{-1}\right)$, diazepam $\left(0.3 \mathrm{mg} \mathrm{kg}^{-1}\right)$, a combination of yohimbine and diazepam (1 and $0.3 \mathrm{mg} \mathrm{kg}^{-1}$ ), or control (vehicle) solution only. The control solution, which was also used to dissolve the drugs, consisted of $0.325 \%$ Tween 80 in $0.9 \%$ phosphate-buffered saline and alcohol $(\mathrm{EtOH})$ at a final concentration of $10 \mu \mathrm{ml}^{-1} \mathrm{EtOH}$.

Behavioral studies. A SMART II Video Tracker system (San Diego Instruments, San Diego, CA, USA) was used to track movement of mice under normal light immediately after drug administration. After injection, mice were placed in the lower right-hand corner of one of four adjacent, 41_41_34$\mathrm{cm}^{3}$ enclosures. Mice had no physical contact with other mice during testing. Each enclosure has nine pre-defined areas, that is, center area, corner areas and wall areas. After an initial $15 \mathrm{~min}$ of adaptation, measures of locomotor activity were obtained from the second half $(15 \mathrm{~min})$ of the total 30-min time recorded immediately after injection of the drugs, with a focus on behavior in the open field center area.

Gene expression studies. Three independent de novo biological experiments, performed at different times, were used for gene expression studies. Each experiment 
consisted of three mice per treatment condition, for a total of nine mice per condition across the three experiments (Figure 1b). Brain and blood from the same de novo experiment were used for microarray studies.

Microdissection. Twenty-four hours after drug administration, mice were sacrificed by cervical dislocation. The brains of the mice were harvested, stereotactically sliced and hand micro-dissected using Paxinos mouse anatomical atlas coordinates, to isolate anatomical regions of interest-PFC, AMY and HIP. ${ }^{25,27,29}$ Tissues were flash frozen in liquid nitrogen and stored at $-80^{\circ} \mathrm{C}$ until future processing for RNA extraction and gene expression analyses. Approximately $1 \mathrm{ml}$ of blood/mouse was collected in PAXgene blood RNAcollection tubes (PreAnalytix, Qiagen, San Jose, CA, USA). The PAXgene tubes were stored at $4{ }^{\circ} \mathrm{C}$ overnight, and then at $-80^{\circ} \mathrm{C}$ until future processing for RNA extraction.

Microarrays. We used Mouse Genome 4302.0 arrays (Affymetrix, Santa Clara, CA, USA). The GeneChip Mouse Genome 4302.0 Array contain over 45000 probe sets that analyze the expression level of over 39000 transcripts and variants from over 34000 well-characterized mouse genes. Microarrays used in each independent experiment were derived from the same manufacturing lot.

RNA extraction and hybridization. For each brain region (PFC, AMY and HIP) and blood, equal amounts of total RNA extracted from tissue samples were pooled within each biological experiment (three mice per treatment group), and then used for labeling and microarray assays.

Standard techniques were used to obtain total RNA (22 gauge syringe homogenization in RLT buffer) and to purify the RNA (RNeasy mini kit, Qiagen) from micro-dissected mouse brain regions. For the whole mouse blood RNA extraction, PAXgene blood RNA extraction kit (PreAnalytiX, a Qiagen/BD Biosciences, San Jose, CA, USA) was used, followed by GLOBINclearTM-Mouse/Rat (Ambion/Applied Biosystems, Austin, TX, USA) to remove the globin mRNA. All the methods and procedures were carried out as per the manufacturer's instructions. The quality of the total RNA was confirmed using an Agilent 2100 Bioanalyzer (Agilent Technologies, Palo Alto, CA, USA). The quantity and quality of total RNA was also independently assessed by $260 \mathrm{~nm}$ ultraviolet absorption and by $260 / 280$ ratios, respectively. Starting material of total RNA labeling reactions was kept consistent within each independent microarray experiment.

Standard Affymetrix protocols were used to reverse transcribe the messenger RNA and generate biotinlylated complementary RNA (http://www.affymetrix.com/support). The amount of complementary RNA used to prepare the hybridization cocktail was kept constant within each experiment. Samples were hybridized at $45^{\circ} \mathrm{C}$ for $17 \mathrm{~h}$ under constant rotation. Arrays were washed and stained using the Affymetrix Fluidics Station 400 and scanned using the Affymetrix Model 3000 Scanner controlled by GCOS software. All sample labeling, hybridization, staining and scanning procedures were carried out as per the manufacturer's recommendations.
Quality control. All arrays were scaled to a target intensity of 1000 using Affymetrix MASv 5.0 array analysis software. Quality control measures including $3^{\prime} / 5^{\prime}$ ratios for glyceraldehyde 3-phosphate dehydrogenase and $\beta$-actin, scaling factors, background and $Q$ values were within acceptable limits.

Microarray data analysis. Data analysis was performed using Affymetrix Microarray Suite 5.0 software (MAS v5.0). Default settings were used to define transcripts as present $(P)$, marginal $(M)$ or absent $(A)$. A comparison analysis was performed for each drug treatment, using its corresponding saline vehicle treatment as the baseline. 'Signal', 'detection', 'signal log ratio', 'change' and 'change $P$-value,' were obtained from this analysis. An empirical $P$-value threshold for change of $P<0.00025$ was used. Only transcripts that were called present in at least one of the two samples (saline vehicle or drug) intra-experiment, and that were reproducibly changed in the same direction in at least two out of three independent experiments, were analyzed further.

Gene identification. The identities of transcripts were established using NetAFFX (Affymetrix). Probe-sets that did not have a known gene were labeled 'EST' and their accession numbers kept as identifiers.

\section{CFG analyses}

Databases. We have established in our laboratory (Laboratory of Neurophenomics, Indiana University School of Medicine, www.neurophenomics.info) manually curated databases of all the human gene expression (postmortem brain, blood), human genetic (association, linkage) and animal model gene expression studies published to date on psychiatric disorders. ${ }^{21}$ Only the findings deemed significant in the primary publication, by the study investigators, using their particular experimental design and thresholds, are included in our databases. These constantly updated large databases have been used in our CFG cross-validation (Figure 1).

Human genetic evidence (association, linkage). To designate convergence for a particular gene, the gene had to have published evidence of association or linkage for anxiety disorders, including PTSD, OCD, panic disorder and phobias. For linkage, the location of each gene was obtained through GeneCards (http://www.genecards.org), and the sex averaged cM location of the start of the gene was then obtained through http://compgen.rutgers.edu/old/mapinterpolator/. For convergence, per our previously published criteria, ${ }^{25}$ the start of the gene had to map within $10 \mathrm{cM}$ of the location of a marker linked to the disorder.

Human gene expression evidence (postmortem brain, blood). Information about genes was obtained and imported in our databases searching the primary literature with PubMed (http://ncbi.nlm.nih.gov/PubMed), using various combinations of keywords (gene name, anxiety, stress, phobia, panic, PTSD, OCD, human, brain, postmortem, blood, lymphocytes, fibroblasts). Convergence was deemed to occur for a gene if there were published human postmortem brain data (or, rarely, blood and other tissue 
data) showing changes in expression of that gene in tissue from patients with anxiety and related disorders.

Mouse genetic evidence (transgenic, QTL). To search for mouse genetic evidence-QTL or transgenic-for our candidate genes, we utilized the MGI_3.54-Mouse Genome Informatics (http://www.informatics.jax.org). (Jackson Laboratory) and used the search 'Genes and Markers' form to find QTL or transgenic for Mammalian Phenotype Ontology category 'abnormal emotion/affect behavior', which includes the following sub-categories: abnormal fear/anxiety-related behavior, abnormal response to novelty and aggression-related behavior. To designate convergence for a particular gene, the gene had to map within $10 \mathrm{cM}$ of a QTL marker for the abnormal behavior, or a transgenic mouse of the gene itself displayed that behavior.

Animal model brain and blood gene expression evidence. For animal model brain and blood gene expression evidence, we have used in addition to our own data, published reports from the literature, curated in our databases.

CFG analysis scoring. Only genes reproducibly changed in expression in the same mouse tissue (PFC, AMY, HIP and blood), in the same direction, in two out of three independent experiments, were analyzed further. The three internal lines of evidence (pharmacological treatmentschanged in yohimbine, changed in diazepam, no change in co-treatment) were scored with 1 point each. The six external cross-validating lines of evidence (three animal models, three human) were: animal model genetic data, animal model brain gene expression data, animal model blood gene expression data, human genetic data, human brain gene expression data and human blood gene expression data (Figure 1d). The lines of evidence received a maximum of 1 point each (for animal model genetic data, 0.5 points if it was QTL, 1 point if it was transgenic; for human genetic data, 0.5 points if it was linkage, 1 point if it was association). Thus the maximum possible CFG score for each gene was $3+6=9$.

The more lines of evidence, that is, the more times a gene shows up as a positive finding across independent studies, platforms, methodologies and species, the higher its CFG score (Figure 1d). This is very similar conceptually to a Google PageRank algorithm, in which the more links to a page, the higher it comes up on the search prioritization list. ${ }^{23}$ Human and animal model, genetic and gene expression, data sets were integrated and tabulated. It has not escaped our attention that other ways of weighing the scores of line of evidence may give slightly different results in terms of prioritization, if not in terms of the list of genes per se. Nevertheless, this simple scoring system, where the different independent lines of evidence are weighted equally, and more of the lines of evidence are related to gene expression rather than genetics, arguably provides a good separation and prioritization of genes and blood biomarkers that are changed in expression and disease relevant, our stated focus.

Pathway analyses. Ingenuity 8.5 (Ingenuity Systems, Redwood City, CA, USA) was used to analyze the biological roles, including top canonical pathways, of the candidate genes resulting from our work (Table 5, Supplementary Table S2), as well as employed to identify genes in our data sets that are the target of existing drugs (Supplementary Table S4). GeneGo (Thompson Reuters) was used to analyze the disease categories of the genes identified (Table 7, Supplementary Table S3).

\section{Results}

Our pharmacogenomics animal model displays a behavioral readout consistent with the drugs having an impact and their intended effects-anxiogenic for yohimbine, anxiolytic for diazepam and mitigation of effects for co-treatment (Figure 2).

We have a relatively large number of genes changed in expression in the mouse tissues examined (three brain regions and blood) (Table 1 ).

To start with, we have grouped the mouse model gene expression changes into categories I-IV, as described in Figure 1c and Table 1 . We reasoned that genes that are category I genes, which are changed in expression by both the agonist and antagonist, as well as not changed ('nipped in the bud') by co-treatment, are more likely to be involved in the core biology of anxiety disorders rather than be pleiotropic effects/side-effects of the drugs we used. Of note, the HIP and the blood have a relatively greater proportion of category I genes than the other brain regions (Table 1), suggesting an important role in anxiety disorders for the HIP, and a possible peripheral effect/biomarker readout for the blood.

For CFG scoring, each internal pharmacological line of evidence (changed in expression by yohimbine, changed by diazepam and not changed by co-treatment) was scored separately, along with each of the six external lines of evidence (three from animal model studies, and three from human studies), resulting in a maximum possible CFG score of 9 (Figure 1). Genes that have a CFG score of 4 or above, i.e. they have at least one full external line of evidence in addition to the maximal possible score of 3 from the internal evidence, were prioritized and shown in Table 2 and Figure 3. The average CFG score for the top candidate genes (Table 2) was again highest for HIP (4.4), followed by AMY (4.37), PFC (4.34) and blood (4.26). The relative role of HIP in anxiety

Table 1 Number of genes reproducibly changed in different regions, classified by categories I-IV

\begin{tabular}{|c|c|c|c|c|c|c|c|}
\hline & $\begin{array}{l}\text { Category I } \\
\text { (\% of total) }\end{array}$ & Category II & $\begin{array}{c}\text { Category III- } \\
\text { diazepam }\end{array}$ & $\begin{array}{c}\text { Category III- } \\
\text { yohimbine }\end{array}$ & $\begin{array}{c}\text { Category IV- } \\
\text { diazepam }\end{array}$ & $\begin{array}{c}\text { Category IV- } \\
\text { yohimbine }\end{array}$ & Total \\
\hline Prefrontal cortex & $4(3.9 \%)$ & 3 & 29 & 32 & 15 & 19 & 102 \\
\hline Amygdala & $4(3.2 \%)$ & 12 & 46 & 32 & 11 & 20 & 125 \\
\hline Hippocampus & $32(10.2 \%)$ & 10 & 56 & 194 & 11 & 11 & 314 \\
\hline Blood & $54(11.0 \%)$ & 41 & 246 & 100 & 36 & 16 & 492 \\
\hline
\end{tabular}




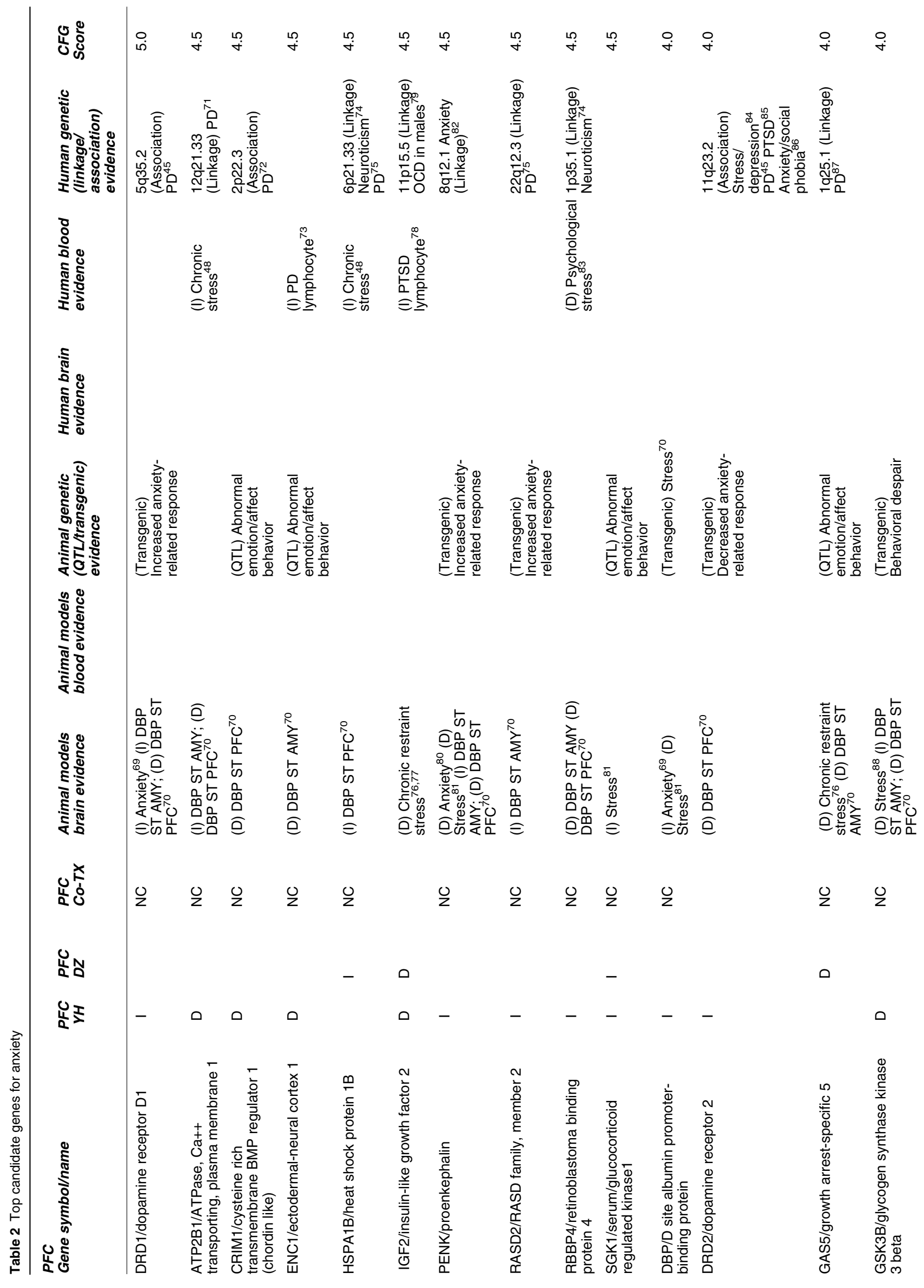




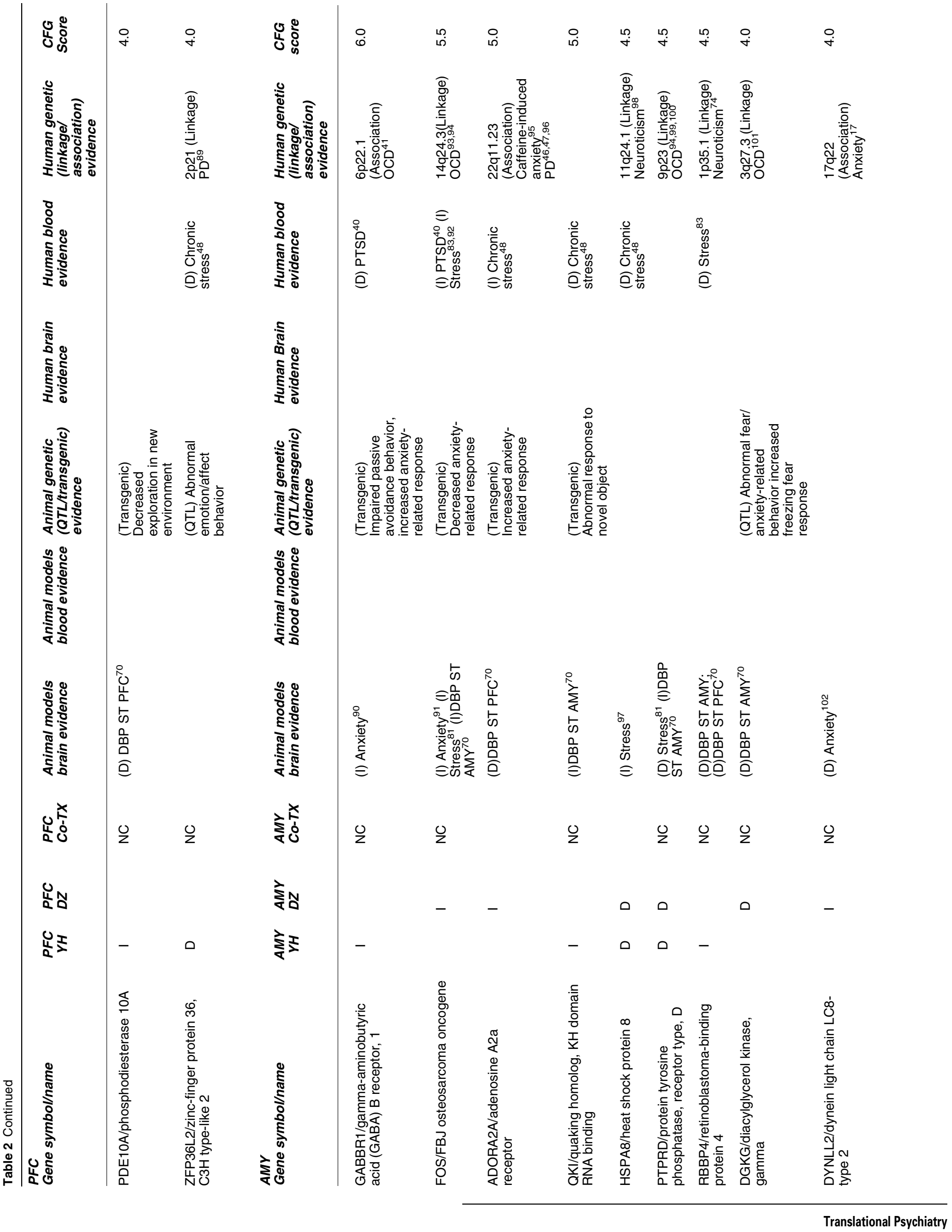




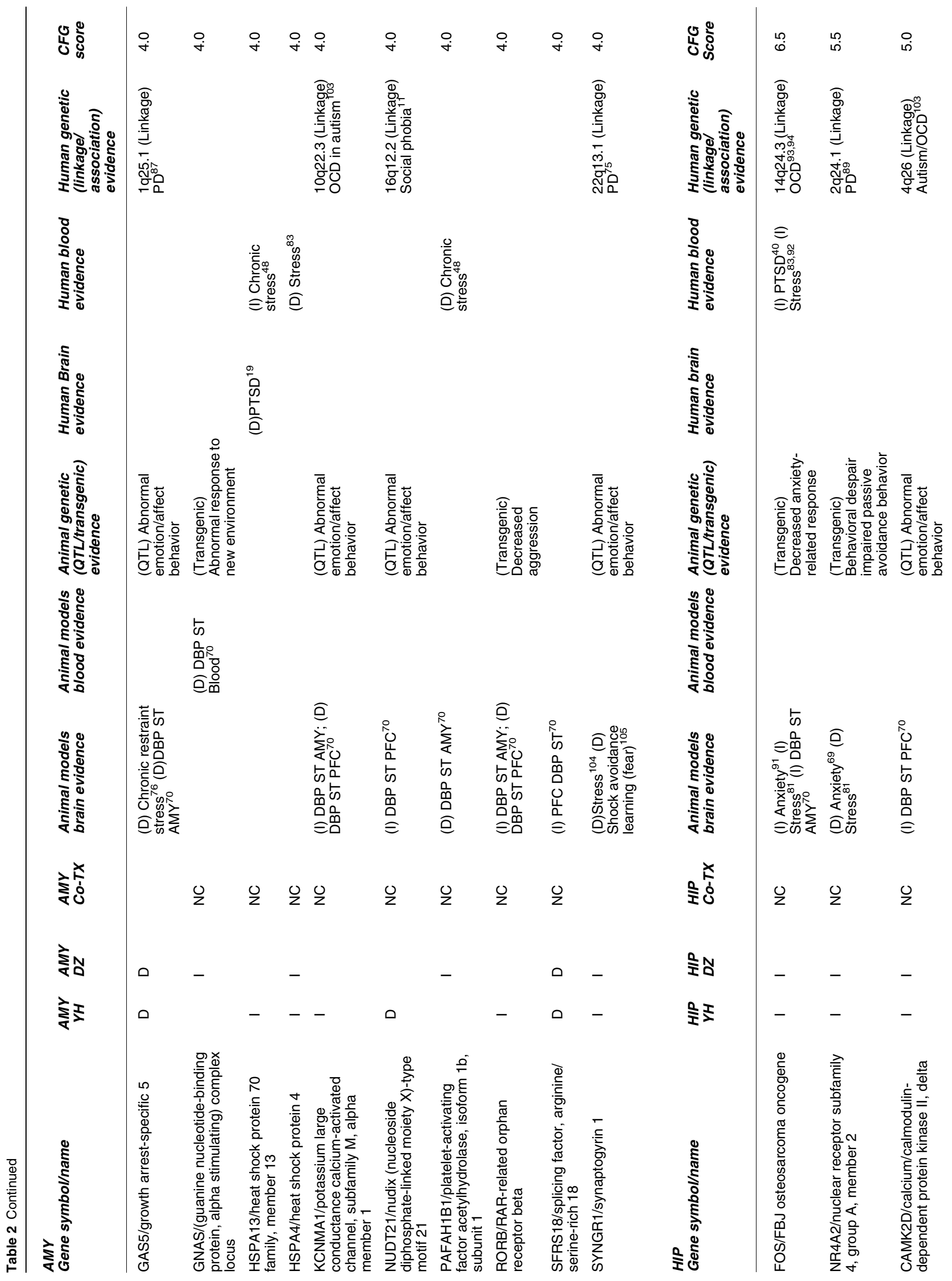




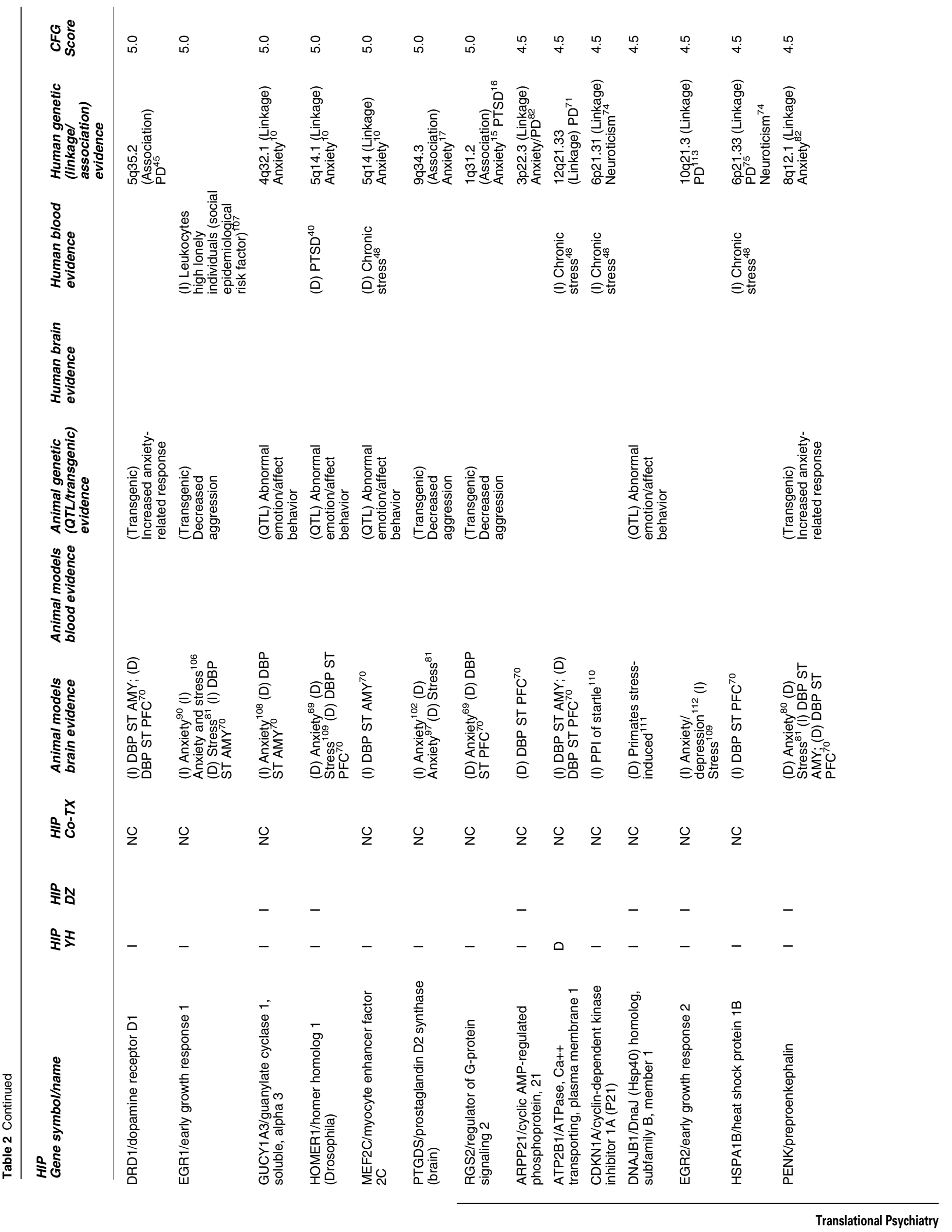




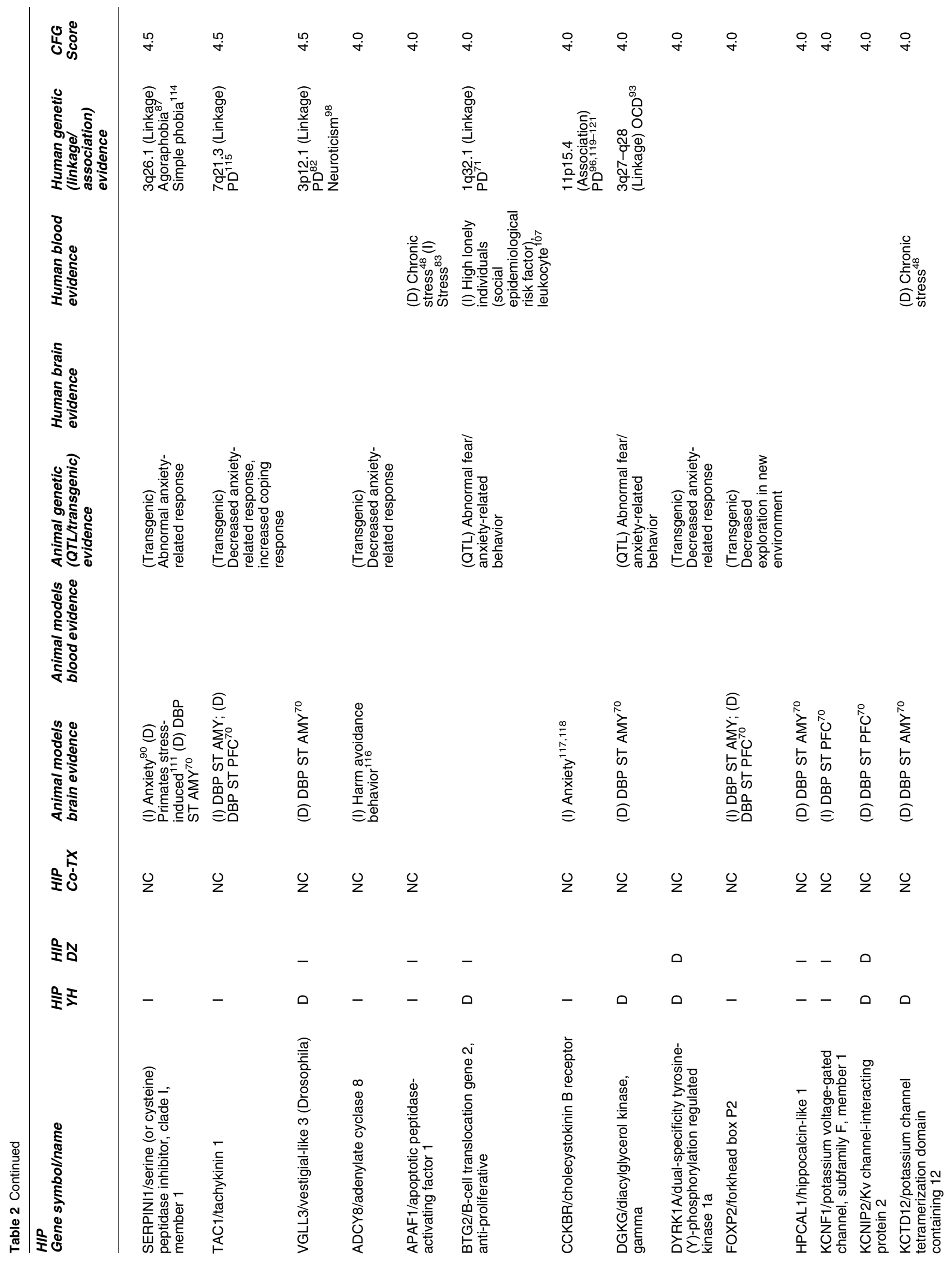




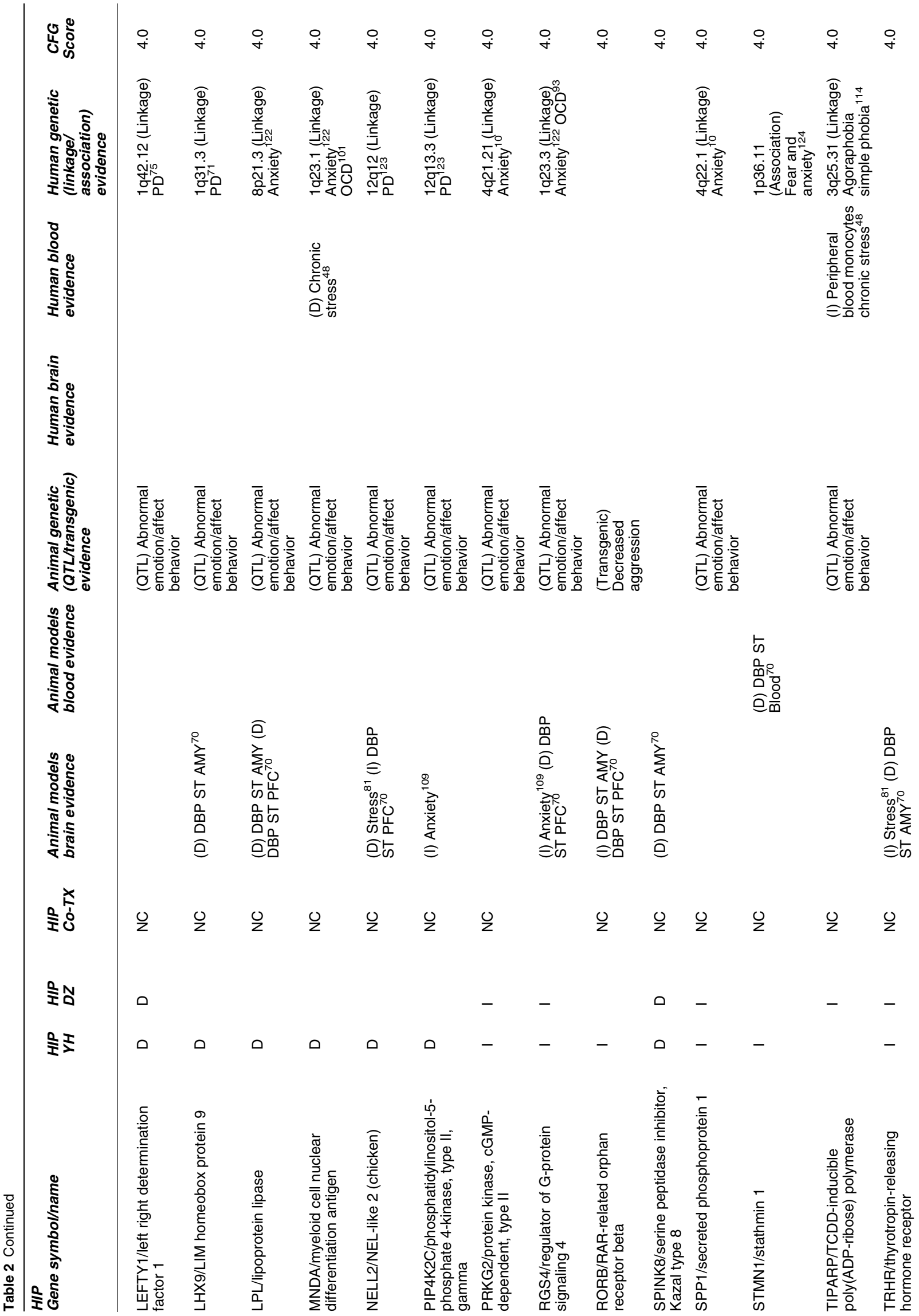




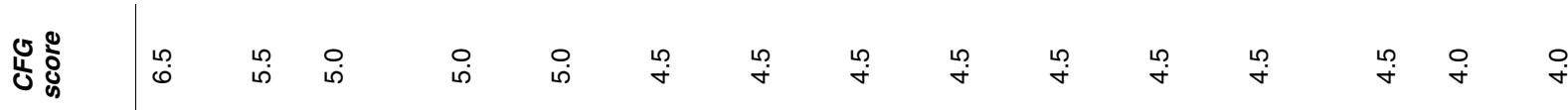

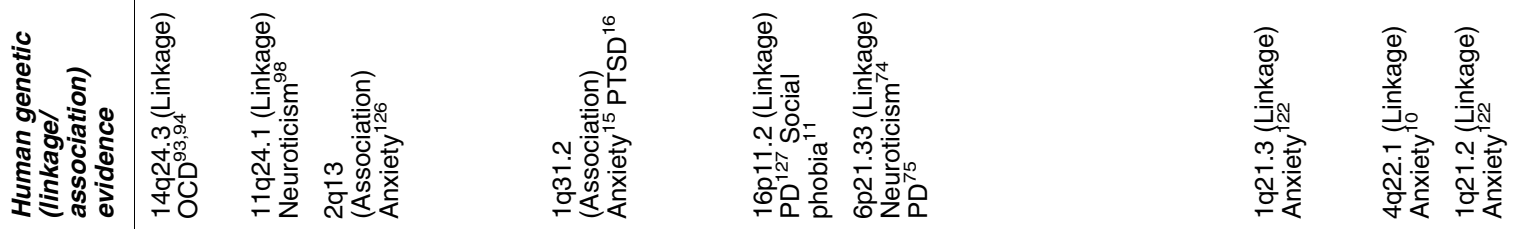

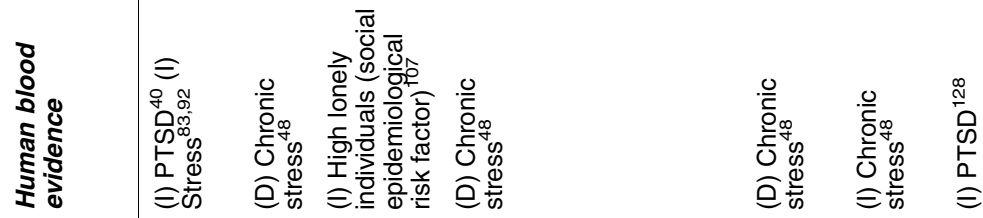
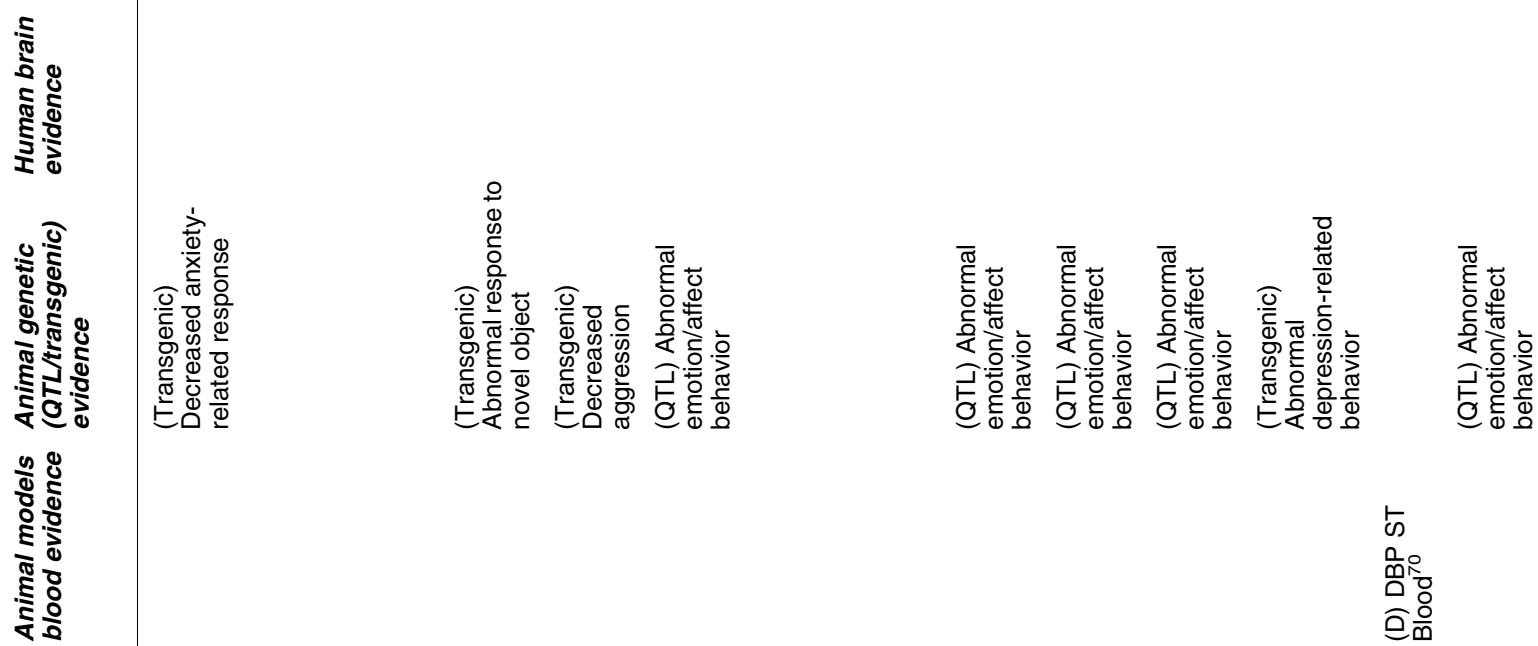

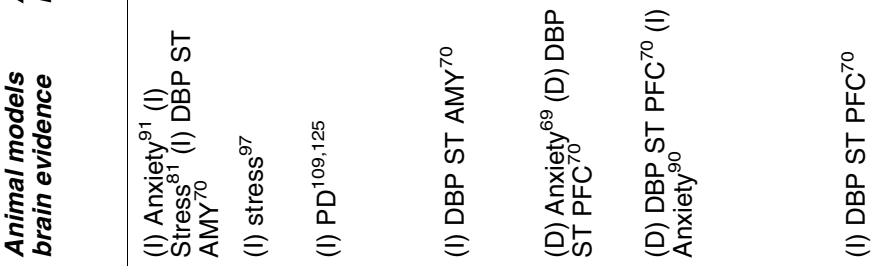

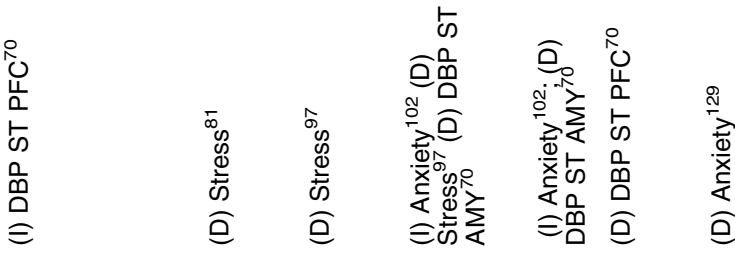

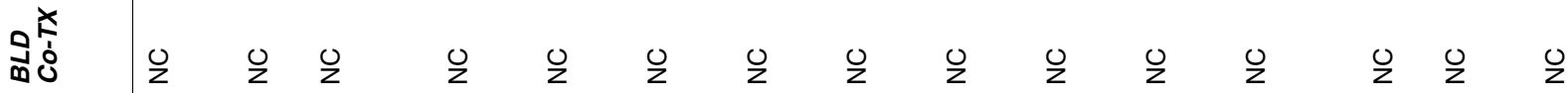

ติำ

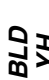

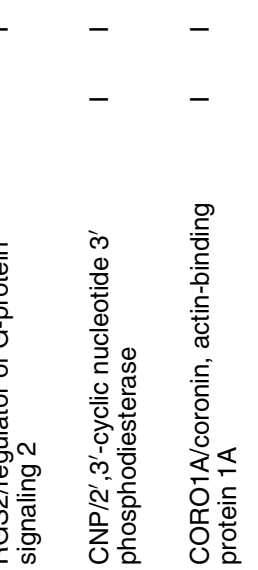

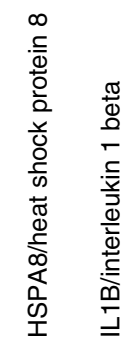

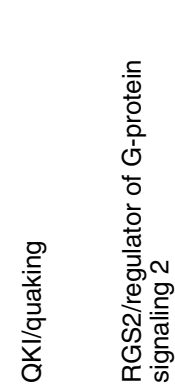

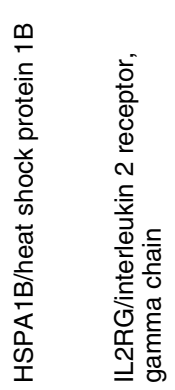

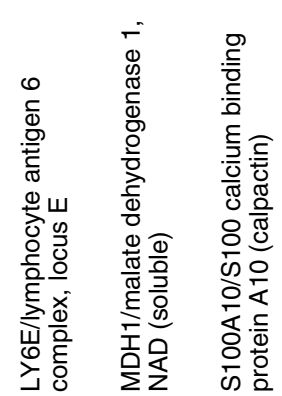

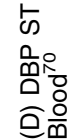




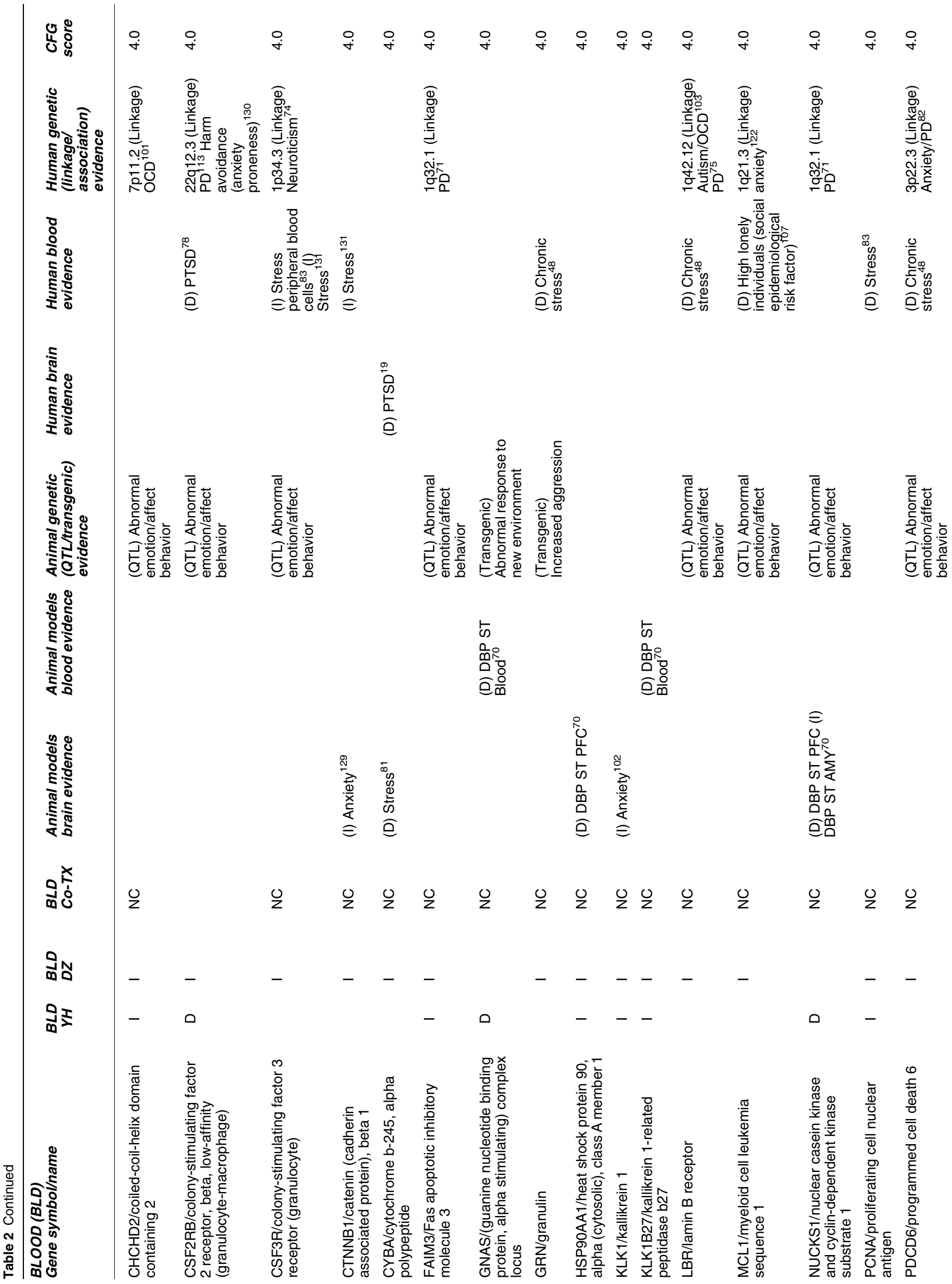




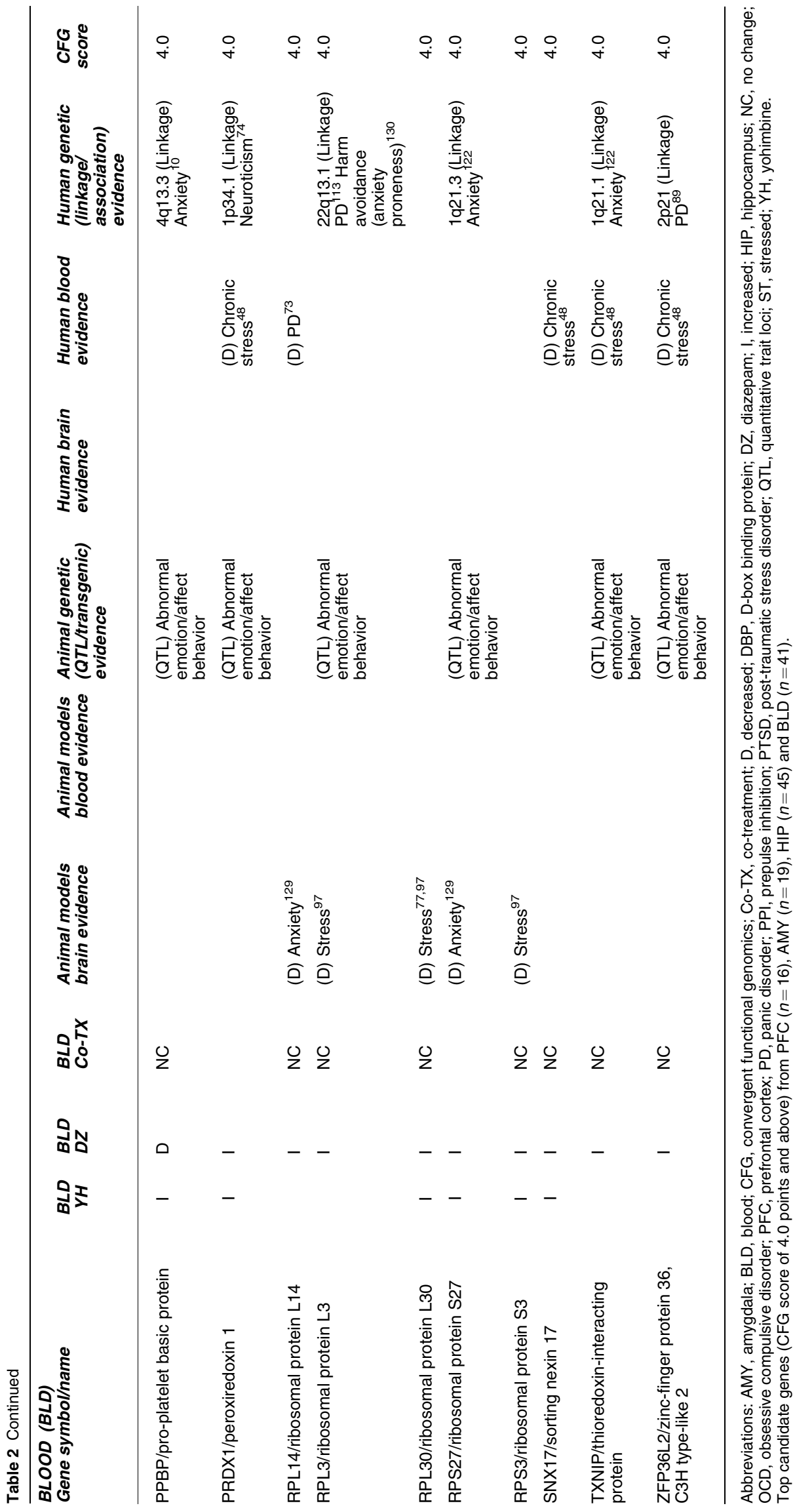




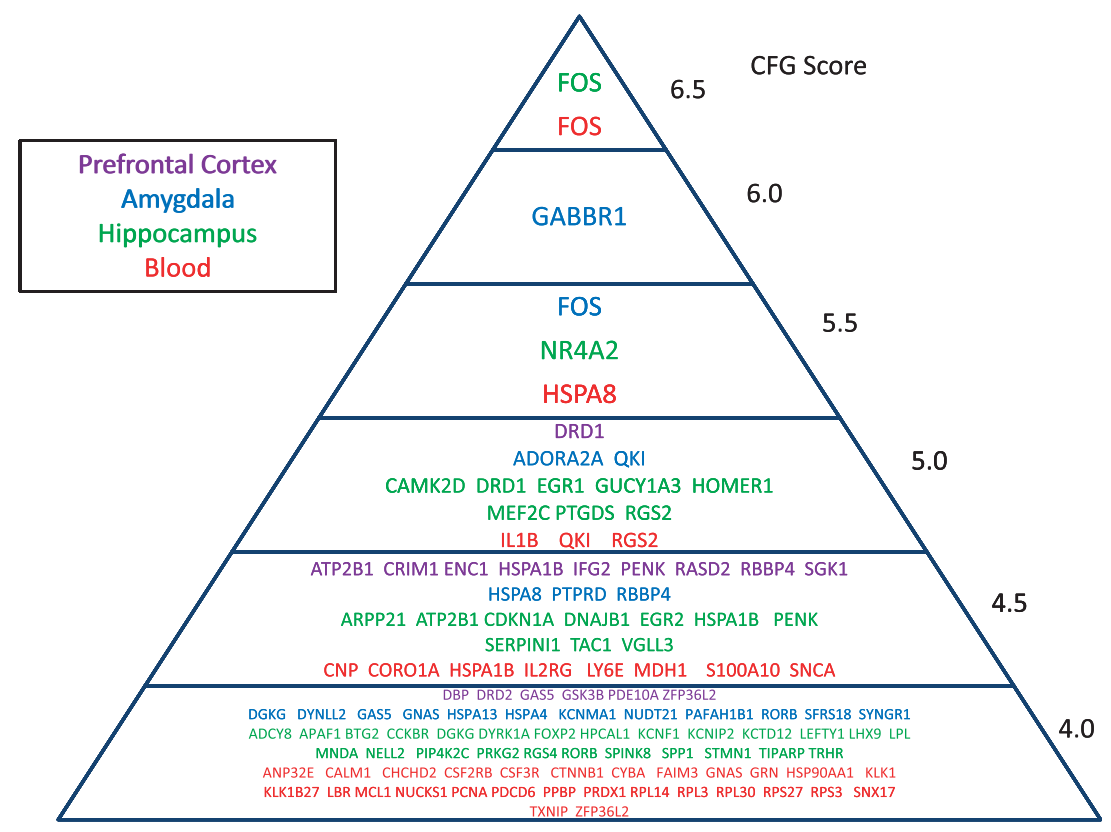

Figure 3 Top candidate genes for anxiety.

disorders may thus be more important than previously appreciated, consistent with recent work in the field. ${ }^{32,39}$

Top candidate genes. Our analysis identified and prioritized a number of top candidate genes (Figure 3 and Table 2), some well-known for involvement in anxiety, some less well known, such as FOS, GABBR1, NR4A2, DRD1, ADORA2A, QKI, RGS2, PTGDS, DYNLL2 and CCKBR. FOS (FBJ murine osteosarcoma viral oncogene homolog) is an oncogene as well as an immediate early response gene. It is a transcription factor involved in cellular reactivity to external signals. In our studies, it is also a top brain-blood biomarker for anxiety, concordantly changed in the AMY, HIP and blood. Interestingly, there is previous evidence of increase in expression of FOS in blood from PTSD patients. ${ }^{40}$ GABBR1 (gamma-aminobutyric acid (GABA) B receptor, 1) has a critical role in the fine-tuning of inhibitory synaptic transmission mediated by GABA. Our work provides evidence for its involvement in the AMY in anxiety (Table 2). Like FOS, it is also changed (decreased) in expression in blood from PTSD patients. ${ }^{40}$ GABBR1 has previous evidence suggestive for genetic association with $\mathrm{OCD}^{41}$ and with schizophrenia. ${ }^{42}$ NR4A2 (nuclear receptor subfamily 4 , group A, member 2 ) is a steroid receptor family member, as well as immediate early response gene. It is a transcription factor involved in cellular reactivity to external signals, with a role in dopaminergic neuron development. Our work provides evidence for its involvement in the HIP in anxiety (Table 2). NR4A2 has previous evidence suggestive for genetic mutations ${ }^{43}$ and brain expression changes ${ }^{44}$ in schizophrenia and bipolar disorder. DRD1 (dopamine receptor 1), for which our work provides evidence for its involvement in the PFC and HIP in anxiety (Table 2), has previous evidence suggestive for genetic association in panic disorder. $^{45}$ ADORA2A (adenosine $\mathrm{A} 2 \mathrm{a}$ receptor), is a receptor for adenosine. The activity of this receptor is mediated by $G$ proteins which activate adenylyl cyclase. Our work provides evidence for the involvement of ADORA2A in the AMY in anxiety (Table 2). There is previous evidence suggestive for genetic association in panic disorder. ${ }^{46,47}$ Notably, with the exception of FOS, all the above discussed top candidate genes for anxiety have also been previously identified by our CFG work as being among top candidate genes for schizophrenia ${ }^{29}$ (Table 6, Supplementary Figure S1). QKI (quaking homolog, $\mathrm{KH}$ domain RNA binding), a RNA-binding protein, has a central role in myelination. In our studies, it is also a top brain-blood biomarker for anxiety, concordantly changed in the AMY and blood. Interestingly, there is previous evidence of increase in expression of QKI in blood from humans subjected to chronic stress. ${ }^{48}$ Finally, among our top candidate genes are RGS2, DYNLL2, PTGDS and CCKBR, all of which have previous human genetic association evidence for anxiety disorders and thus serve as a de facto positive control for our pharmacogenomic approach. Of note, PTGDS and CCKBR are also top candidate genes for schizophrenia in our previous work $^{29}$ (Table 6, Supplementary Figure S1).

In addition, we have looked at what genes were changed in expression in all three brain regions studied (Table 3 ), on the premise they are more likely to be involved in the core biology of anxiety. Notably, EGR2 (early growth response 2) and SGK1 (serum/glucocorticoid-regulated kinase 1), which are involved in cellular reactivity to external signals and stress, have high CFG scores (i.e. multiple converging lines of evidence) for involvement in anxiety disorders.

Biomarkers. Genes that are changed in expression in one of the key brain regions studied and in blood are candidate blood biomarkers. ${ }^{22}$ We used a narrow interpretation of what can constitute a candidate blood biomarker (Table 4), i.e. the 

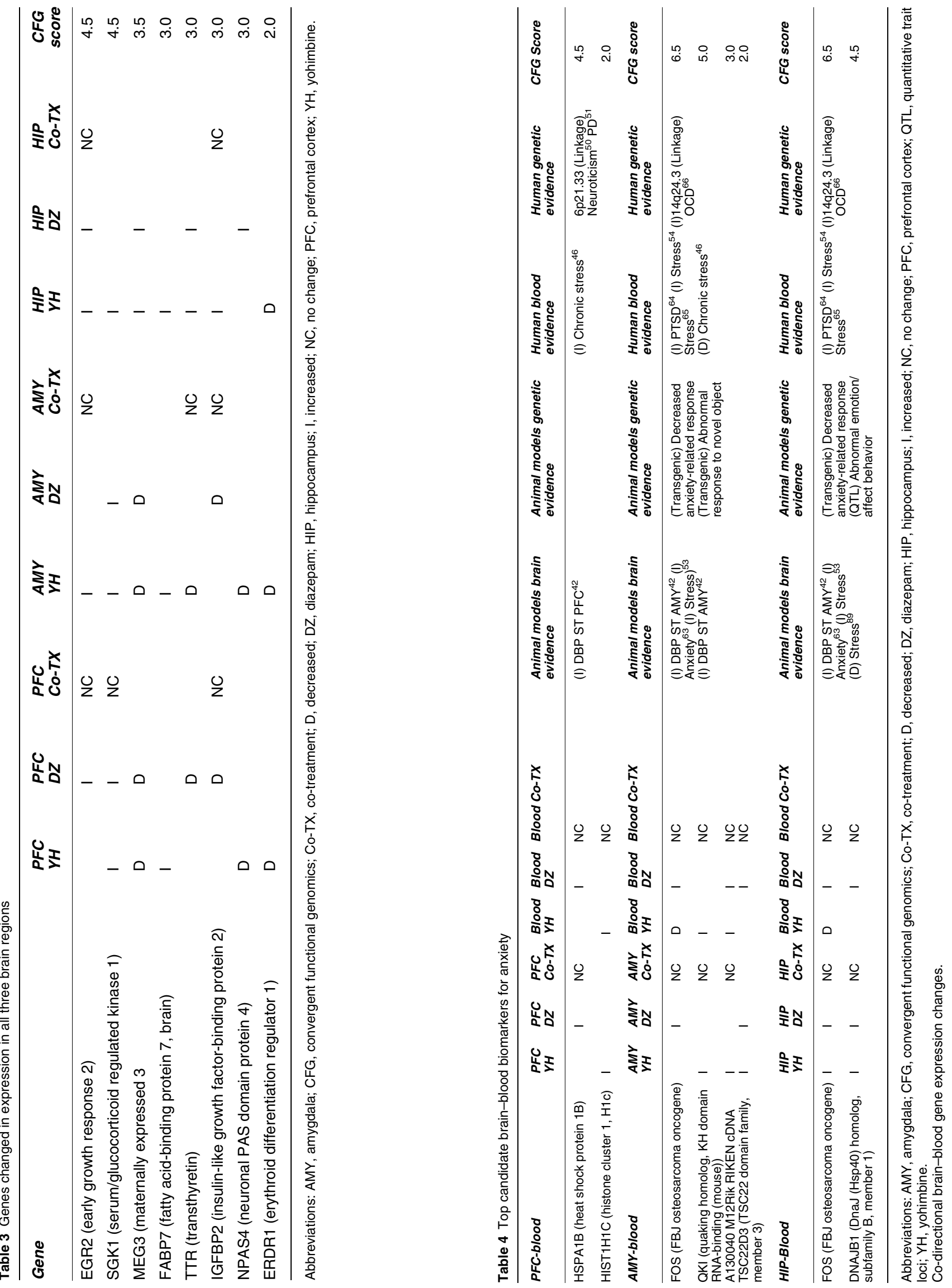
change in gene expression in brain and blood has to be codirectional, inside the same drug treatment arm. FOS, QKI, HSPA1B and DNAJB1 are the top candidate biomarkers under this definition. There is more overlap between brain and blood if co-directionality of expression is not a criterion (Supplementary Table S1), as different tissues (and brain regions) can show different directions of gene expression changes. Moreover, there may be an even more significant overlap between brain and blood at a biological pathway level (Table 5 and Figure 4), where the same top pathways, if not

Table 5 Biological pathway analyses of top candidate genes

\begin{tabular}{|c|c|c|}
\hline Top Canonical Pathways & P-value & Ratio \\
\hline $\begin{array}{l}\text { PFC ( } \mathrm{n}=16 \text { genes) } \\
\text { cAMP-mediated signaling } \\
\text { Huntington's disease signaling } \\
\text { Dopamine receptor signaling } \\
\text { Glioma signaling } \\
\text { PTEN signaling }\end{array}$ & $\begin{array}{r}1.33 \mathrm{E}-03 \\
1.65 \mathrm{E}-03 \\
3.69 \mathrm{E}-03 \\
5.11 \mathrm{E}-03 \\
5.6 \mathrm{E}-03\end{array}$ & $\begin{array}{r}3 / 217(0.014) \\
3 / 246(0.012) \\
2 / 93(0.022) \\
2 / 116(0.017) \\
2 / 123(0.016)\end{array}$ \\
\hline $\begin{array}{l}\text { AMY }(\mathrm{n}=19 \text { genes }) \\
\text { Aldosterone signaling in epithelial cells } \\
\text { Protein ubiquitination pathway } \\
\text { cAMP-mediated signaling } \\
\text { Glucocorticoid receptor signaling } \\
\text { CCR5 signaling in macrophages }\end{array}$ & $\begin{array}{l}3.51 \mathrm{E}-05 \\
2.15 \mathrm{E}-04 \\
1.85 \mathrm{E}-03 \\
3.21 \mathrm{E}-03 \\
3.37 \mathrm{E}-03\end{array}$ & $\begin{array}{r}4 / 172(0.023) \\
4 / 274(0.015) \\
3 / 217(0.014) \\
3 / 284(0.011) \\
2 / 95(0.021)\end{array}$ \\
\hline $\begin{array}{l}\text { HIP }(\mathrm{n}=45 \text { genes) } \\
\text { cAMP-mediated signaling } \\
\text { Corticotropin releasing hormone signaling } \\
\text { GNRH signaling } \\
\text { G-protein coupled receptor signaling } \\
\text { Antiproliferative role of somatostatin } \\
\text { receptor } 2\end{array}$ & $\begin{array}{l}2.39 \mathrm{E}-04 \\
2.89 \mathrm{E}-04 \\
3.58 \mathrm{E}-04 \\
3.83 \mathrm{E}-04 \\
1.08 \mathrm{E}-03\end{array}$ & $\begin{array}{r}5 / 217(0.023) \\
4 / 137(0.029) \\
4 / 145(0.028) \\
7 / 531(0.013) \\
3 / 81(0.037)\end{array}$ \\
\hline $\begin{array}{l}\text { Blood ( } \mathrm{n}=41 \text { genes) } \\
\text { Glucocorticoid receptor signaling } \\
\text { CCR5 signaling in macrophages } \\
\text { PPAR signaling } \\
\text { Role of osteoblasts, osteoclasts and } \\
\text { chondrocytes in rheumatoid arthritis } \\
\text { Huntington's disease signaling }\end{array}$ & $\begin{array}{l}5.21 \mathrm{E}-04 \\
9.33 \mathrm{E}-04 \\
1.84 \mathrm{E}-03 \\
2.67 \mathrm{E}-03 \\
2.88 \mathrm{E}-03\end{array}$ & $\begin{array}{r}5 / 284(0.018) \\
3 / 95(0.032) \\
3 / 106(0.028) \\
4 / 243(0.016) \\
4 / 246(0.016)\end{array}$ \\
\hline
\end{tabular}

Abbreviations: AMY, amygdala; CFG, convergent functional genomics; HIP hippocampus; PFC, prefrontal cortex.

Ingenuity Pathway Analyses of top candidate genes (CFG score of 4.0 and up). necessarily the same genes, show alterations. Notably the glucocorticoid receptor signaling pathway and the CCR5 signaling pathway are altered in anxiety in both AMY and blood. In the end, panels of biomarkers and pathways need to be clinically validated, i.e. show predictive ability for anxiety state or response to treatment in independent human studies.

Pathways. First, we carried out biological pathway analyses on all the genes that were changed in expression in our pharmacogenomic model, without any CFG prioritization (Supplementary Table S2). This may give a view of pathways involved in anxiety in the brain, but probably includes other pleiotropic effects of the drugs used.

Next, we carried out pathway analyses on the top candidate genes prioritized by CFG (CFG score of 4.0 and above) (Table 5). The resulting pathways are likely more specific to the core illness phenomenology, and less pleiotropic. Among these top biological pathways altered in anxiety, cAMP is changed in common in all three brain regions studied (Figure 4). cAMP signaling is fundamental to cellular reactivity to external signals. Previous evidence has been suggestive of a role for CAMP signaling pathways in anxiety disorders, ${ }^{49-51}$ but our work is the first to identify it as a core mechanism for anxiety across different brain regions.

We also identified biological pathways involved in anxiety specific to the different brain regions we studied. In the PFC, after cAMP signaling, the top pathway is Huntington's disease signaling. This pathway is also a top pathway altered in the blood in our analyses, suggesting its potential as a biomarker repository (Figure 4). In the AMY, the top pathway is aldosterone signaling. Previous work in animal models has suggested a role for the mineralocorticoid pathway in anxiety and stress response. ${ }^{52}$ Glucocorticoid receptor signaling and CCR5 signaling are other top pathways in the AMY, as well as in blood (Figure 4). In the HIP, after cAMP signaling, the top pathway is corticotropin-releasing hormone signaling. This pathway is well established in anxiety and stress

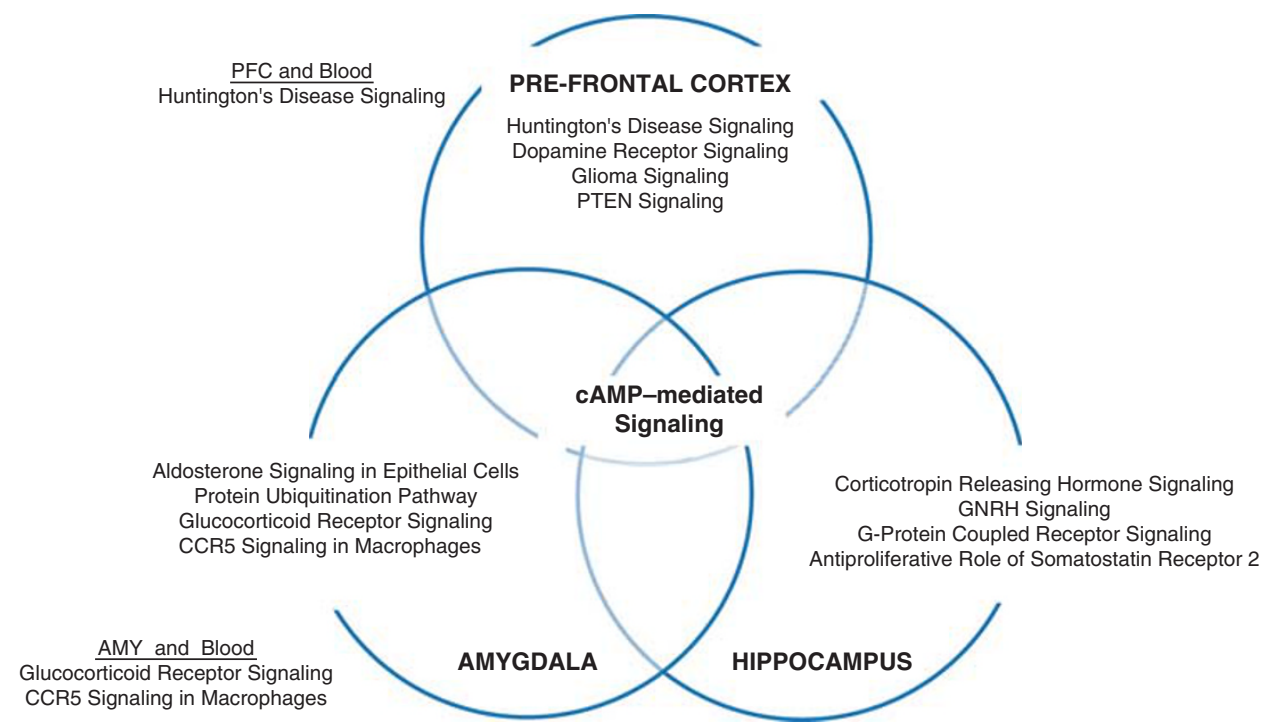

Figure 4 Top biological pathways for anxiety in different brain regions. Overlap between brain regions, and with the blood. 
response, ${ }^{53,54}$ and serves as a reassuring positive control for our own work and analyses.

\section{Discussion}

We have used a comprehensive, CFG approach for identifying high probability candidate genes, pathways and mechanisms for anxiety and related disorder, by the integration in a Bayesian fashion of multiple independent converging lines of evidence. This mapping of the genomic landscape of anxiety disorders completes our triad of first-pass mapping efforts of major psychiatric disorders domains-bipolar disorder, ${ }^{25,26,55}$ schizophrenia, ${ }^{29}$ and now anxiety disorders.

Our convergent approach emphasizes gene expression evidence more than genetic evidence, i.e. more of the scored lines of evidence come from gene expression studies than from genetic studies (Figure 1). Gene expression studies are arguably a better way to understand biology than genetic studies. After all, gene expression is the result of integration of the effects of many genetic polymorphisms, epigenetic changes and environmental effects, whereas genetics looks too early in this chain of events, and in a narrow fashion. Biologically important genes can thus be identified and studied in action at a gene expression level, whereas at a genetic level the complexity and heterogeneity of genetic polymorphisms precludes easy identification and gives no indication of their actual biological activity. The advantage of gene expression studies over genetic studies, including sequencing, may be magnified by evolutionary considerations of increased genetic heterogeneity in highly biologically active and environmentally reactive genes, such as brain and immune system genes, as a way of permitting adaptation to the environment. ${ }^{23}$ Moreover, as per our earlier formulation that 'genes that change together (may) act together', ${ }^{24}$ the co-expression data sets we have generated in various brain regions offer testable hypotheses for transcriptional co-regulation, and for epistatic interactions among the corresponding loci. ${ }^{56}$

Limitations and confounds. An acute treatment model like the one we are using is not necessarily inductive to assessing the long-term changes associated with anxiety, such as functional and structural changes apparent on imaging. Although we have no direct way of knowing if some of the genes we captured with our screen are involved or not in setting in motion such long-term changes, it is to be noted that some of these gene changes have also been reported in genetic studies of anxiety and anxiety-related disorders. Moreover, we have candidate genes in our data set with roles in brain infrastructure, including myelination (Table 2). More chronic treatments should, nevertheless, be pursued to verify and expand the findings presented in this paper.

Different combinations of anxiogenic and anxiolytic agents could be used in a comprehensive functional pharmacogenomic approach such as the one we have described. They could conceivably lead to different results, which would be of interest and welcome, since it is unlikely we are capturing with our model the full spectrum of gene expression changes involved in anxiety. However, if those drug combinations indeed mimic and modulate the same core phenomenology, the Venn diagrams of the overlap between different drug treatments will be of high interest in terms of identifying the key molecular players involved in the effects, as opposed to those involved in the (very different) side-effects of the individual drugs.

It is to be noted that our experimental approach for detecting gene expression changes relies on a single methodology, Affymetrix GeneChip oligonucleotide microarrays. It is possible that some of the gene expression changes detected from a single biological experiment, with a one-time assay with this technology, are biological or technical artifacts. With that in mind, we have designed our experiments to minimize the likelihood of having false positives, even at the expense of having false negatives. Working with an isogenic mouse strain affords us an ideal control baseline of saline vehicle injected animals for our drug-injected animals. We performed three independent de novo biological experiments, at different times, with different batches of mice (Figure 1b). We have pooled material from three mice in each experiment, and carried out microarray studies. The pooling process introduces a built in averaging of signal. We used a Venn diagram approach and only considered the genes that were reproducibly changed in the same direction in at least two out of three independent experiments. This overall design is geared to factor out both biological and technical variability. It is to be noted that the concordance between reproducible microarray experiments using the latest generations of oligonucleotide microarrays and other methodologies such as quantitative PCR, with their own attendant technical limitations, is estimated to be over $90 \%{ }^{57}$ Moreover, our CFG approach, as described above, is predicated on the existence of multiple internal and external cross-validators for each gene that is reproducibly changed in expression (Figure 1 ). These crossvalidators are derived from independent gene expression or genetic experiments.

Conclusions and future directions. The results presented in this paper have a series of direct implications. First, in terms of pharmacotherapy and drug development, some of the candidate genes in our data set encode for proteins that are modulated by existing pharmacological agents (Supplementary Table S4), which may suggest future avenues for rational polypharmacy using currently available agents. Notably, existing drugs approved for other indications, such as dopaminergic agents, ion channel blockers, baclofen, nitrates, lipid modulators and disulfiram (Antabuse) are potential augmentation options for existing first-line anxiolytics and merit careful exploration as such. Some of the top anxiety candidate genes (FOS, PTGDS, HOMER1, NR4A2, GSK3B and LPL) are also modulated by the omega-3 fatty acid DHA in recent animal model studies carried by us (Le-Niculescu et al., Transl Psychiatry (2011) 1, e4, doi:10.1038/tp.2011.1), providing a potential nonpharmacological alternative for treatment. Our data sets of the effects of yohimbine and diazepam on gene expression in different key brain regions (Table 2) may be used as a source of new targets for drug development. The candidate biomarkers identified by us may, upon future validation, aid with drug development, monitoring response to treatment 
Table 6 Gene Overlap Across Psychiatric Disorders: a CFG view

\begin{tabular}{|c|c|c|c|}
\hline Anxiety & Bipolar ${ }^{25,26,55}$ & Schizophrenia ${ }^{29}$ & Alcohol ${ }^{\beta 1}$ \\
\hline $\begin{array}{l}\text { ADORA2A } \\
\text { BTG2 } \\
\text { CCKBR } \\
\text { DBP } \\
\text { DRD1 } \\
\text { DRD2 } \\
\text { FOXP2 } \\
\text { GABBR1 } \\
\text { GNAS } \\
\text { GSK3B } \\
\text { LPL } \\
\text { MEF2C } \\
\text { NR4A2 } \\
\text { PDE10A } \\
\text { PENK } \\
\text { PTGDS } \\
\text { RGS4 } \\
\text { RORB } \\
\text { TAC1 }\end{array}$ & $\begin{array}{l}\text { GSK3B }^{26} \\
\text { MEF2C }^{25} \\
\text { PDE10A }^{26} \\
\text { PENK }^{25}\end{array}$ & $\begin{array}{l}\text { ADORA2A } \\
\text { CCKBR } \\
\text { DRD1 } \\
\text { DRD2 } \\
\text { FOXP2 } \\
\text { GABBR1 } \\
\text { LPL } \\
\text { NR4A2 } \\
\text { PDE10A } \\
\text { PTGDS } \\
\text { RGS4 } \\
\text { TAC1 }\end{array}$ & BTG2 \\
\hline
\end{tabular}

Abbreviation: CFG, convergent functional genomics.

Top anxiety CFG candidate genes are also top CFG candidate genes for other major psychiatric disorders based on our previous studies. ${ }^{25,26,31,55}$

and early clinical intervention. Heterogeneity is possible, indeed likely, in individual human subjects - a fertile direction for future studies. ${ }^{26,28,30}$ Targeting key pathways identified by us (Figure 4) may provide broader options than targeting individual genes, for both drug development and peripheral blood readouts.

Second, despite using lines of evidence for our CFG approach that have to do only with anxiety disorders, the list of genes identified has a notable overlap with other psychiatric disorders, and with medical disorders (Tables 5 and 7 , Supplementary Tables S2 and S3). This is a topic of major interest and debate in the field. ${ }^{58,59}$ We demonstrate an overlap between top candidate genes for anxiety and candidate genes for schizophrenia and bipolar disorder, as well as alcoholism previously identified by us through CFG (Table 6 and Supplementary Figure S1), thus providing a possible molecular basis for the frequently observed clinical co-morbidity and interdependence between anxiety and those other major psychiatric disorders. Notably, PDE10A and TAC1 are at the overlap of all three major psychiatric domains, and may be of major interest for drug development. ${ }^{60-62}$ Among our top candidate genes for anxiety are $D B P$ and $R O R B$, circadian clock genes previously identified by us as candidate genes for bipolar disorder ${ }^{27,55,63}$ (Table 6 and Supplementary Figure S1). In addition to mood symptoms, we had previously demonstrated that DBP knock-out mice exhibit increased reactivity to stress, as well as increased alcohol consumption. ${ }^{27}$ NPAS4, another circadian gene in our anxiety dataset, is changed in expression in all three brain regions studied (Table 3). NPAS4 is a transcription factor that acts as a heterodimer partner for $A R N T L$, another top candidate gene for bipolar disorder identified by our previous work. ${ }^{25,26,64}$ The involvement of circadian genes in anxiety may underlie anxiety effects on sleep, diurnal variations in anxiety (for example, higher at night), and cycling in levels of anxiety symptoms in some patients-similar too, driven by or driving mood symptoms (cycloanxiety vs cyclothymia). ${ }^{6}$ Another top
Table 7 Disease analyses for top candidate genes

\begin{tabular}{|c|c|c|}
\hline $\begin{array}{l}\text { GeneGo disease analyses } \\
\text { Disease }\end{array}$ & P-value & Ratio \\
\hline \multicolumn{3}{|l|}{$P F C(\mathrm{n}=16$ genes $)$} \\
\hline Depressive disorder, major & $3.101 e-14$ & $10 / 133$ \\
\hline Depressive disorder & $1.034 \mathrm{e}-12$ & $10 / 188$ \\
\hline Mood disorders & $3.462 \mathrm{e}-12$ & $12 / 410$ \\
\hline Parkinson disease & $2.453 e-11$ & $11 / 361$ \\
\hline Parkinsonian disorders & $5.961 e-11$ & $11 / 392$ \\
\hline \multicolumn{3}{|l|}{$A M Y(\mathrm{n}=19$ genes $)$} \\
\hline Mood disorders & $5.074 \mathrm{e}-7$ & $8 / 41$ \\
\hline Friedreich ataxia & $5.087 e-7$ & 3 \\
\hline Agoraphobia & $7.258 \mathrm{e}-7$ & $3 / 10$ \\
\hline Fibrosis & $1.546 \mathrm{e}-6$ & $8 / 475$ \\
\hline Genetic syndromes sometimes & $3.362 e-6$ & $3 / 16$ \\
\hline associated with diabetes & & \\
\hline \multicolumn{3}{|l|}{ HIP $(\mathrm{n}=45$ genes $)$} \\
\hline Mental disorders & $7.094 \mathrm{e}-15$ & $41 / 229$ \\
\hline Psychiatry and psychology & $1.303 e-14$ & $41 / 2329$ \\
\hline Schizophrenia & $5.021 \mathrm{e}-14$ & $26 / 838$ \\
\hline $\begin{array}{l}\text { Schizophrenia and disorders } \\
\text { with psychotic features }\end{array}$ & $5.618 e-14$ & $26 / 842$ \\
\hline Cough & $1.975 e-12$ & $7 / 17$ \\
\hline \multicolumn{3}{|l|}{ Blood $(\mathrm{n}=41$ genes $)$} \\
\hline $\begin{array}{l}\text { Schizophrenia and disorders } \\
\text { with psychotic features }\end{array}$ & $4.592 e-9$ & $16 / 842$ \\
\hline Wounds and injuries & $4.708 e-9$ & $17 / 977$ \\
\hline Urogenital neoplasms & $1.930 \mathrm{e}-8$ & $25 / 2531$ \\
\hline Genital diseases, male & $3.695 e-8$ & $24 / 2391$ \\
\hline Schizophrenia & $3.736 \mathrm{e}-8$ & $15 / 838$ \\
\hline
\end{tabular}

Abbreviations: AMY, amygdala; CFG, convergent functional genomics; HIP, hippocampus; PFC, prefrontal cortex.

Disease grouping analysis of top candidate genes (CFG score of 4.0 and up). GeneGo analyses.

candidate gene at the overlap of bipolar disorder and anxiety is PENK (preproenkephalin). Our work provides evidence for the involvement of PENK in the PFC and HIP in anxiety (Table 2). Endogenous opiates may signal that the environment is favorable, improving mood and decreasing anxiety. As such, exogenous opiate drugs may be effective for treatment, but highly addictive. Unexpectedly, there is a major overlap between schizophrenia and anxiety, both at a top candidate genes level (Supplementary Figure S1 and Table 6) and at a pathway analyses level (Table 7 and Supplementary Table S3). Clinically, while there are some reports of co-morbidity between schizophrenia and anxiety, ${ }^{65-67}$ it is an area that has possibly been under-appreciated and understudied. Based on our work and the body of evidence in the field, we propose that a new diagnostic category of 'schizoanxiety disorder' may have heuristic value and pragmatic clinical utility, similar to schizoaffective disorder.

Third, the mechanistic understanding and model for anxiety that emerges out of the candidate gene identified and the analyses of biological pathways involved points to signal transduction and reactivity to signals from the external environment and internal milieu (Figure 5). Notably, pathways involved in cellular stress and heat shock response (involving HSPA1B, HSPA8, HSPA4, HSPA13) seem to have been recruited by evolution for higher whole-body and mental functions ${ }^{68}$ such as anxiety. The cybernetic-like simplicity of the model should not overshadow the important fact that it is 


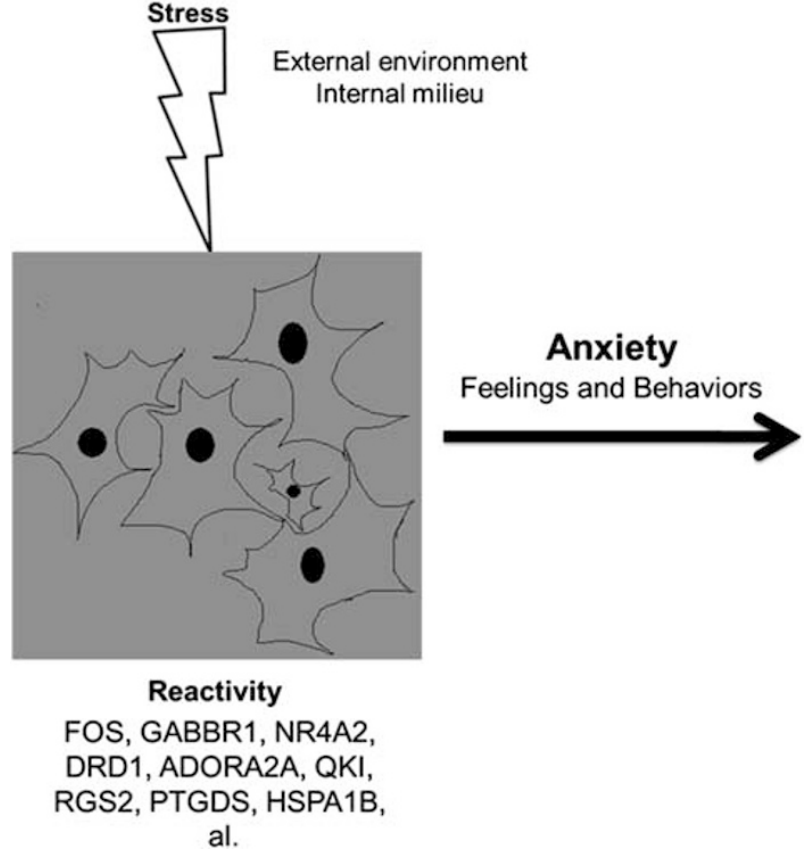

Figure 5 Anxiety disorders: reactivity to the environment.

the result of the empirical coalescence of data in a nonhypothesis driven, discovery type approach. The implications for understanding the pathophysiology and treatment of anxiety and related disorders are profound. One needs to correct cellular, brain and whole organism reactivity to the environment in the treatment of these disorders. It is a place where psychopharmacology, management of medical problems, cognitive-behavioral therapy and social integration can and should go hand in hand.

In conclusion, we propose that our comprehensive CFG approach is a useful starting point in helping unravel the complex genetic code and neurobiology of anxiety and related disorders, and generates a series of leads for both future research and clinical practice.

\section{Conflict of interest}

The authors declare no conflict of interest.

Acknowledgements. We would like to acknowledge our debt of gratitude for the efforts and results of the many other groups, cited in our paper, who have conducted empirical studies (animal model and human, genetic and gene expression) in anxiety disorders. Without their arduous and careful work, a convergent approach such as ours would not be possible. This work was supported by an NIH Directors' New Innovator Award (1DP2OD007363) and a VA Merit Award (1101CX000139-01) to ABN. Microarray studies were carried out in the Center for Medical Genomics at Indiana University School of Medicine.

1. Kessler RC, Berglund P, Demler O, Jin R, Merikangas KR, Walters EE. Lifetime prevalence and age-of-onset distributions of DSM-IV disorders in the National Comorbidity Survey Replication. Arch Gen Psychiatry 2005; 62: 593-602.

2. Lepine JP. The epidemiology of anxiety disorders: prevalence and societal costs. J Clin Psychiatry 2002; 63(Suppl 14): 4-8.

3. Kessler RC, Chiu WT, Demler O, Merikangas KR, Walters EE. Prevalence, severity, and comorbidity of 12-month DSM-IV disorders in the National Comorbidity Survey Replication. Arch Gen Psychiatry 2005; 62: 617-627.
4. Dannon PN, Lowengrub K, Shalgi B, Sasson M, Tuson L, Saphir Y et al. Dual psychiatric diagnosis and substance abuse in pathological gamblers: a preliminary gender comparison study. J Addict Dis 2006; 25: 49-54.

5. Dilsaver SC, Akiskal HS, Akiskal KK, Benazzi F. Dose-response relationship between number of comorbid anxiety disorders in adolescent bipolar/unipolar disorders, and psychosis, suicidality, substance abuse and familiality. J Affect Disord 2006; 96: 249-258

6. Niculescu III AB, Schork NJ, Salomon DR. Mindscape: a convergent perspective on life, mind, consciousness and happiness. J Affect Disord 2010; 123: 1-8.

7. Shin RA, Belmonte PL, Zandi PP. A review of the evidence from family, twin and adoption studies for a genetic contribution to adult psychiatric disorders. Int Rev Psychiatry 2004; 16: $260-283$.

8. Skre I, Onstad S, Torgersen S, Lygren S, Kringlen E. A twin study of DSM-III-R anxiety disorders. Acta Psychiatr Scand 1993; 88: 85-92.

9. Hamilton SP. Linkage and association studies of anxiety disorders. Depress Anxiety 2009; 26: 976-983.

10. Kaabi B, Gelernter J, Woods SW, Goddard A, Page GP, Elston RC. Genome scan for loci predisposing to anxiety disorders using a novel multivariate approach: strong evidence for a chromosome 4 risk locus. Am J Hum Genet 2006; 78: 543-553.

11. Gelernter J, Page GP, Stein MB, Woods SW. Genome-wide linkage scan for loci predisposing to social phobia: evidence for a chromosome 16 risk locus. Am J Psychiatry 2004; 161: 59-66.

12. Smoller JW, Yamaki LH, Fagerness JA, Biederman J, Racette S, Laird NM et al. The corticotropin-releasing hormone gene and behavioral inhibition in children at risk for panic disorder. Biol Psychiatry 2005; 57: 1485-1492.

13. Arnold PD, Sicard T, Burroughs E, Richter MA, Kennedy JL. Glutamate transporter gene SLC1A1 associated with obsessive-compulsive disorder. Arch Gen Psychiatry 2006; 63: 769-776.

14. Hohoff C, Mullings EL, Heatherley SV, Freitag CM, Neumann LC, Domschke K et al. Adenosine $\mathrm{A}(2 \mathrm{~A})$ receptor gene: evidence for association of risk variants with panic disorder and anxious personality. J Psychiatr Res 2010; 44: 930-937.

15. Smoller JW, Paulus MP, Fagerness JA, Purcell S, Yamaki LH, Hirshfeld-Becker D et al. Influence of RGS2 on anxiety-related temperament, personality, and brain function. Arch Gen Psychiatry 2008; 65: 298-308.

16. Amstadter $\mathrm{AB}$, Koenen $\mathrm{KC}$, Ruggiero KJ, Acierno R, Galea S, Kilpatrick DG et al. Variant in RGS2 moderates posttraumatic stress symptoms following potentially traumatic event exposure. J Anxiety Disord 2009; 23: 369-373.

17. Donner J, Pirkola S, Silander K, Kananen L, Terwilliger JD, Lonnqvist $\mathrm{J}$ et al. An association analysis of murine anxiety genes in humans implicates novel candidate genes for anxiety disorders. Biol Psychiatry 2008; 64: 672-680.

18. Bracha HS, Garcia-Rill E, Mrak RE, Skinner R. Postmortem locus coeruleus neuron count in three American veterans with probable or possible war-related PTSD. J Neuropsychiatry Clin Neurosci 2005; 17: 503-509.

19. Su YA, Wu J, Zhang L, Zhang Q, Su DM, He P et al. Dysregulated mitochondrial genes and networks with drug targets in postmortem brain of patients with posttraumatic stress disorder (PTSD) revealed by human mitochondria-focused cDNA microarrays. Int J Biol Sci 2008; 4: 223-235

20. Bertsch B, Ogden CA, Sidhu K, Le-Niculescu H, Kuczenski R, Niculescu AB. Convergent functional genomics: a Bayesian candidate gene identification approach for complex disorders. Methods 2005; 37: 274-279.

21. Niculescu AB, Le-Niculescu H. Convergent functional genomics: what we have learned and can learn about genes, pathways, and mechanisms. Neuropsychopharmacology 2010; 35: 355-356.

22. Le-Niculescu H, McFarland MJ, Mamidipalli S, Ogden CA, Kuczenski R, Kurian SM et al. Convergent functional genomics of bipolar disorder: from animal model pharmacogenomics to human genetics and biomarkers. Neurosci Biobehav Rev 2007; 31: 897-903.

23. Le-Niculescu H, Patel SD, Niculescu AB. Convergent integration of animal model and human studies of bipolar disorder (manic-depressive illness). Curr Opin Pharmacol 2010, 10: $594-600$.

24. Niculescu A, Segal D, Kuczenski R, Barrett T, Hauger R, Kelsoe J. Identifying a series of candidate genes for mania and psychosis: a convergent functional genomics approach. Physiological Genomics 2000; 4: 83-91.

25. Ogden CA, Rich ME, Schork NJ, Paulus MP, Geyer MA, Lohr JB et al. Candidate genes, pathways and mechanisms for bipolar (manic-depressive) and related disorders: an expanded convergent functional genomics approach. Mol Psychiatry 2004; 9 : 1007-1029.

26. Patel SD, Le-Niculescu H, Koller DL, Green SD, Lahiri DK, McMahon FJ et al. Coming to grips with complex disorders: genetic risk prediction in bipolar disorder using panels of genes identified through convergent functional genomics. Am J Med Genet B Neuropsychiatr Genet 2010; 153B: 850-877.

27. Le-Niculescu H, McFarland MJ, Ogden CA, Balaraman Y, Patel S, Tan J et al. Phenomic convergent functional genomic, and biomarker studies in a stress-reactive genetic animal model of bipolar disorder and co-morbid alcoholism. Am J Med Genet B Neuropsychiatr Genet 2008; 147B: 134-166.

28. Le-Niculescu H, Kurian SM, Yehyawi N, Dike C, Patel SD, Edenberg HJ et al. Identifying blood biomarkers for mood disorders using convergent functional genomics. Mol Psychiatry 2009; 14: 156-174. 
29. Le-Niculescu H, Balaraman Y, Patel S, Tan J, Sidhu K, Jerome RE et al. Towards understanding the schizophrenia code: an expanded convergent functional genomics approach. Am J Med Genet B Neuropsychiatr Genet 2007; 144: 129-158.

30. Kurian SM, Le-Niculescu H, Patel SD, Bertram D, Davis J, Dike $C$ et al. Identification of blood biomarkers for psychosis using convergent functional genomics. Mol Psychiatry 2011; 16: 37-58.

31. Rodd ZA, Bertsch BA, Strother WN, Le-Niculescu H, Balaraman Y, Hayden E et al. Candidate genes, pathways and mechanisms for alcoholism: an expanded convergent functional genomics approach. Pharmacogenomics J 2007; 7: 222-256.

32. Oler JA, Fox AS, Shelton SE, Rogers J, Dyer TD, Davidson RJ et al. Amygdalar and hippocampal substrates of anxious temperament differ in their heritability. Nature 2010; 466: 864-868.

33. Charney DS, Woods SW, Goodman WK, Heninger GR. Neurobiological mechanisms of panic anxiety: biochemical and behavioral correlates of yohimbine-induced panic attacks. Am J Psychiatry 1987; 144: 1030-1036.

34. Risbrough VB, Geyer MA. Anxiogenic treatments do not increase fear-potentiated startle in mice. Biol Psychiatry 2005; 57: 33-43.

35. Vasa RA, Pine DS, Masten CL, Vythilingam M, Collin C, Charney DS et al. Effects of yohimbine and hydrocortisone on panic symptoms, autonomic responses, and attention to threat in healthy adults. Psychopharmacology (Berl) 2009; 204: 445-455.

36. Risbrough VB, Brodkin JD, Geyer MA. GABA-A and 5-HT1A receptor agonists block expression of fear-potentiated startle in mice. Neuropsychopharmacology 2003; 28 654-663.

37. Li S, Murakami Y, Wang M, Maeda K, Matsumoto K. The effects of chronic valproate and diazepam in a mouse model of posttraumatic stress disorder. Pharmacol Biochem Behav 2006; 85: 324-331.

38. Shekhar A, McCann UD, Meaney MJ, Blanchard DC, Davis M, Frey KA et al. Summary of a National Institute of Mental Health workshop: developing animal models of anxiety disorders. Psychopharmacology (Berl) 2001; 157: 327-339.

39. Eren-Kocak E, Turner CA, Watson SJ, Akil H. Short-Hairpin RNA silencing of endogenous fibroblast growth factor 2 in rat hippocampus increases anxiety behavior Biol Psychiatry 2011; 69: 534-540.

40. Segman RH, Shefi N, Goltser-Dubner T, Friedman N, Kaminski N, Shalev AY. Peripheral blood mononuclear cell gene expression profiles identify emergent post-traumatic stress disorder among trauma survivors. Mol Psychiatry 2005; 10: 500-513, 425

41. Zai G, Arnold P, Burroughs E, Barr CL, Richter MA, Kennedy JL. Evidence for the gamma-amino-butyric acid type $B$ receptor 1 (GABBR1) gene as a susceptibility factor in obsessive-compulsive disorder. Am J Med Genet B Neuropsychiatr Genet 2005; 134: 25-29.

42. Zai G, King N, Wong GW, Barr CL, Kennedy JL. Possible association between the gamma-aminobutyric acid type B receptor 1 (GABBR1) gene and schizophrenia. Eur Neuropsychopharmacol 2005; 15: 347-352.

43. Buervenich S, Carmine A, Arvidsson M, Xiang F, Zhang Z, Sydow $O$ et al. NURR1 mutations in cases of schizophrenia and manic-depressive disorder. Am J Med Genet 2000; 96: 808-813.

44. Xing G, Zhang L, Russell S, Post R. Reduction of dopamine-related transcription factors Nurr1 and NGFI-B in the prefrontal cortex in schizophrenia and bipolar disorders. Schizophr Res 2006; 84: 36-56.

45. Maron E, Nikopensius T, Koks S, Altmae S, Heinaste E, Vabrit K et al. Association study of 90 candidate gene polymorphisms in panic disorder. Psychiatr Genet 2005; 15 $17-24$.

46. Deckert J, Nothen MM, Franke P, Delmo C, Fritze J, Knapp M et al. Systematic mutation screening and association study of the A1 and A2a adenosine receptor genes in panic disorder suggest a contribution of the A2a gene to the development of disease. Mol Psychiatry 1998; 3: 81-85.

47. Hamilton SP, Slager SL, De Leon AB, Heiman GA, Klein DF, Hodge SE et al. Evidence for genetic linkage between a polymorphism in the adenosine $2 \mathrm{~A}$ receptor and panic disorder. Neuropsychopharmacology 2004; 29: 558-565.

48. Miller GE, Chen E, Sze J, Marin T, Arevalo JM, Doll R et al. A functional genomic fingerprint of chronic stress in humans: blunted glucocorticoid and increased NF-kappaB signaling. Biol Psychiatry 2008; 64: 266-272.

49. Krishnan V, Graham A, Mazei-Robison MS, Lagace DC, Kim KS, Birnbaum S et al. Calcium-sensitive adenylyl cyclases in depression and anxiety: behavioral and biochemical consequences of isoform targeting. Biol Psychiatry 2008; 64: 336-343.

50. Duman $\mathrm{CH}$, Duman RS. Neurobiology and treatment of anxiety: signal transduction and neural plasticity. Handb Exp Pharmacol 2005; 169: 305-334.

51. Pandey SC, Zhang H, Roy A, Xu T. Deficits in amygdaloid cAMP-responsive elementbinding protein signaling play a role in genetic predisposition to anxiety and alcoholism. $J$ Clin Invest 2005; 115: 2762-2773.

52. Hlavacova N, Bakos J, Jezova D. Eplerenone, a selective mineralocorticoid receptor blocker, exerts anxiolytic effects accompanied by changes in stress hormone release. J Psychopharmacol 2010; 24: 779-786.

53. Magalhaes AC, Holmes KD, Dale LB, Comps-Agrar L, Lee D, Yadav PN et al. CRF receptor 1 regulates anxiety behavior via sensitization of $5-\mathrm{HT} 2$ receptor signaling. Nat Neurosci 2010; 13: 622-629.

54. Binder EB, Nemeroff CB. The CRF system, stress, depression and anxiety-insights from human genetic studies. Mol Psychiatry 2010; 15: 574-588.
55. Niculescu III AB, Segal DS, Kuczenski R, Barrett T, Hauger RL, Kelsoe JR. Identifying a series of candidate genes for mania and psychosis: a convergent functional genomics approach. Physiol Genomics 2000; 4: 83-91.

56. Nicodemus KK, Law AJ, Radulescu E, Luna A, Kolachana B, Vakkalanka R et al. Biological validation of increased schizophrenia risk with NRG1, ERBB4, and AKT1 epistasis via functional neuroimaging in healthy controls. Arch Gen Psychiatry 2010; 67: 991-1001.

57. Quackenbush J. Genomics. Microarrays-guilt by association. Science 2003; 302: 240-241.

58. Huang J, Perlis RH, Lee PH, Rush AJ, Fava M, Sachs GS et al. Cross-disorder genomewide analysis of schizophrenia, bipolar disorder, and depression. Am J Psychiatry 2010; 167: 1254-1263.

59. Smoller JW, Gardner-Schuster E, Misiaszek M. Genetics of anxiety: would the genome recognize the DSM? Depress Anxiety 2008; 25: 368-377.

60. Charych El, Jiang LX, Lo F, Sullivan K, Brandon NJ. Interplay of palmitoylation and phosphorylation in the trafficking and localization of phosphodiesterase $10 \mathrm{~A}$ : implications for the treatment of schizophrenia. J Neurosci 2010; 30: 9027-9037.

61. Frisch P, Bilkei-Gorzo A, Racz I, Zimmer A. Modulation of the $\mathrm{CRH}$ system by substance P/NKA in an animal model of depression. Behav Brain Res 2010; 213: 103-108

62. Mathew SJ, Vythilingam M, Murrough JW, Zarate Jr CA, Feder A, Luckenbaugh DA et al. A selective neurokinin-1 receptor antagonist in chronic PTSD: a randomized, doubleblind, placebo-controlled, proof-of-concept trial. Eur Neuropsychopharmacol 2011; 21: 221-229.

63. McGrath CL, Glatt SJ, Sklar P, Le-Niculescu H, Kuczenski R, Doyle AE et al. Evidence for genetic association of RORB with bipolar disorder. BMC Psychiatry 2009; 9: 70 .

64. Le-Niculescu H, Patel SD, Bhat M, Kuczenski R, Faraone SV, Tsuang MT et al. Convergent functional genomics of genome-wide association data for bipolar disorder: comprehensive identification of candidate genes, pathways and mechanisms. Am J Med Genet B Neuropsychiatr Genet 2009; 150B: 155-181.

65. Lysaker PH, Yanos PT, Outcalt J, Roe D. Association of stigma, self-esteem, and symptoms with concurrent and prospective assessment of social anxiety in schizophrenia. Clin Schizophr Relat Psychoses 2010; 4: 41-48.

66. Michail M, Birchwood M. Social anxiety disorder in first-episode psychosis: incidence, phenomenology and relationship with paranoia. Br J Psychiatry 2009; 195: 234-241.

67. Buckley PF, Miller BJ, Lehrer DS, Castle DJ. Psychiatric comorbidities and schizophrenia. Schizophr Bull 2009; 35: 383-402.

68. Uchida S, Hara K, Kobayashi A, Fujimoto M, Otsuki K, Yamagata $\mathrm{H}$ et al. Impaired hippocampal spinogenesis and neurogenesis and altered affective behavior in mice lacking heat shock factor 1. Proc Natl Acad Sci USA 2011; 108: 1681-1686.

69. Mozhui K, Karlsson RM, Kash TL, Ihne J, Norcross M, Patel S et al. Strain differences in stress responsivity are associated with divergent amygdala gene expression and glutamate-mediated neuronal excitability. J Neurosci 2010; 30: 5357-5367.

70. Le-Niculescu H, McFarland M, Ogden C, Balaraman Y, Patel S, Tan J et al. Phenomic, convergent functional genomic, and biomarker studies in a stress-reactive genetic animal model of bipolar disorder and co-morbid alcoholism. Am J Med Genet B 2008; 147B: 134-166.

71. Weissman MM, Fyer AJ, Haghighi F, Heiman G, Deng Z, Hen R et al. Potential panic disorder syndrome: clinical and genetic linkage evidence. Am J Med Genet 2000; 96: 24-35.

72. Erhardt A, Czibere L, Roeske D, Lucae S, Unschuld PG, Ripke S et al. TMEM132D, a new candidate for anxiety phenotypes: evidence from human and mouse studies. $\mathrm{Mol}$ Psychiatry, advance online publication, 6 April 2010.

73. Philibert RA, Crowe R, Ryu GY, Yoon JG, Secrest D, Sandhu H et al. Transcriptional profiling of lymphoblast lines from subjects with panic disorder. Am J Med Genet B Neuropsychiatr Genet 2007; 144B: 674-682.

74. Nash MW, Huezo-Diaz P, Williamson RJ, Sterne A, Purcell S, Hoda F et al. Genome-wide linkage analysis of a composite index of neuroticism and mood-related scales in extreme selected sibships. Hum Mol Genet 2004; 13: 2173-2182.

75. Hamilton SP, Fyer AJ, Durner M, Heiman GA, Baisre de Leon A, Hodge SE et al. Further genetic evidence for a panic disorder syndrome mapping to chromosome 13q. Proc Nat Acad Sci USA 2003; 100: 2550-2555.

76. Ejchel-Cohen TF, Wood GE, Wang JF, Barlow K, Nobrega JN, B SM et al. Chronic restraint stress decreases the expression of glutathione S-transferase pi2 in the mouse hippocampus. Brain Res 2006; 1090: 156-162.

77. Andrus BM, Blizinsky K, Vedell PT, Dennis K, Shukla PK, Schaffer DJ et al. Gene expression patterns in the hippocampus and amygdala of endogenous depression and chronic stress models. Mol Psychiatry; advance online publication, 16 November 2010 .

78. Zieker J, Zieker D, Jatzko A, Dietzsch J, Nieselt K, Schmitt A et al. Differential gene expression in peripheral blood of patients suffering from post-traumatic stress disorder. Mol Psychiatry 2007; 12: 116-118.

79. Wang JC, Grucza R, Cruchaga C, Hinrichs AL, Bertelsen S, Budde JP et al. Genetic variation in the CHRNA5 gene affects mRNA levels and is associated with risk for alcohol dependence. Mol Psychiatry 2009; 14: 501-510. 
80. Bilkei-Gorzo A, Racz I, Michel K, Zimmer A, Klingmuller D, Zimmer A. Behavioral phenotype of pre-proenkephalin-deficient mice on diverse congenic backgrounds. Psychopharmacology (Berl) 2004; 176: 343-352.

81. Reyes TM, Walker JR, DeCino C, Hogenesch JB, Sawchenko PE. Categorically distinct acute stressors elicit dissimilar transcriptional profiles in the paraventricular nucleus of the hypothalamus. J Neurosci 2003; 23: 5607-5616.

82. Thorgeirsson TE, Oskarsson H, Desnica N, Kostic JP, Stefansson JG, Kolbeinsson H et al. Anxiety with panic disorder linked to chromosome $9 q$ in Iceland. Am J Hum Genet 2003; 72: 1221-1230.

83. Morita K, Saito T, Ohta M, Ohmori T, Kawai K, Teshima-Kondo S et al. Expression analysis of psychological stress-associated genes in peripheral blood leukocytes. Neurosci Lett 2005; 381: 57-62.

84. Elovainio M, Jokela M, Kivimaki M, Pulkki-Raback L, Lehtimaki T, Airla N et al. Genetic variants in the DRD2 gene moderate the relationship between stressful life events and depressive symptoms in adults: cardiovascular risk in young Finns study. Psychosom Med 2007; 69: 391-395.

85. Lawford BR, Young R, Noble EP, Kann B, Ritchie T. The D2 dopamine receptor (DRD2) gene is associated with co-morbid depression, anxiety and social dysfunction in untreated veterans with post-traumatic stress disorder. Eur Psychiatry 2006; 21 180-185.

86. Sipila T, Kananen L, Greco D, Donner J, Silander K, Terwilliger JD et al. An association analysis of circadian genes in anxiety disorders. Biol Psychiatry 2010; 67: 1163-1170.

87. Gelernter J, Bonvicini K, Page G, Woods SW, Goddard AW, Kruger S et al. Linkage genome scan for loci predisposing to panic disorder or agoraphobia. Am J Med Genet 2001; 105: 548-557.

88. Omata N, Chiu CT, Moya PR, Leng Y, Wang Z, Hunsberger JG et al. Lentivirally mediated GSK-3beta silencing in the hippocampal dentate gyrus induces antidepressant-like effects in stressed mice. Int J Neuropsychopharmacol 2011; 14: 711-717.

89. Fyer AJ, Hamilton SP, Durner M, Haghighi F, Heiman GA, Costa R et al. A third-pass genome scan in panic disorder: evidence for multiple susceptibility loci. Biol Psychiatry 2006; 60: 388-401.

90. Wang $\mathrm{H}$, Zhu YZ, Wong PT, Farook JM, Teo AL, Lee LK et al. cDNA microarray analysis of gene expression in anxious PVG and SD rats after cat-freezing test. Exp Brain Res 2003; 149: 413-421.

91. Plaza-Zabala A, Martin-Garcia E, de Lecea L, Maldonado R, Berrendero F. Hypocretins regulate the anxiogenic-like effects of nicotine and induce reinstatement of nicotineseeking behavior. J Neurosci 2010; 30: 2300-2310.

92. Ohmori T, Morita K, Saito T, Ohta M, Ueno S, Rokutan K. Assessment of human stress and depression by DNA microarray analysis. J Med Invest 2005; 52(Suppl): 266-271.

93. Samuels J, Shugart YY, Grados MA, Willour VL, Bienvenu OJ, Greenberg BD et al. Significant linkage to compulsive hoarding on chromosome 14 in families with obsessivecompulsive disorder: results from the OCD Collaborative Genetics Study. Am J Psychiatry 2007; 164: 493-499.

94. Liang KY, Wang Y, Shugart YY, Grados M, Fyer AJ, Rauch S et al. Evidence for potential relationship between SLC1A1 and a putative genetic linkage region on chromosome 14q to obsessive-compulsive disorder with compulsive hoarding. Am J Med Genet B Neuropsychiatr Genet 2008; 147B: 1000-1002.

95. Rogers PJ, Hohoff C, Heatherley SV, Mullings EL, Maxfield PJ, Evershed RP et al. Association of the anxiogenic and alerting effects of caffeine with ADORA2A and ADORA1 polymorphisms and habitual level of caffeine consumption Neuropsychopharmacology 2010; 35: 1973-1983.

96. Maron E, Hettema JM, Shlik J. Advances in molecular genetics of panic disorder. $\mathrm{Mol}$ Psychiatry 2010; 15: 681-701.

97. Lee HC, Chang DE, Yeom M, Kim GH, Choi KD, Shim I et al. Gene expression profiling in hypothalamus of immobilization-stressed mouse using cDNA microarray. Brain Res $\mathrm{Mol}$ Brain Res 2005; 135: 293-300.

98. Neale BM, Sullivan PF, Kendler KS. A genome scan of neuroticism in nicotine dependent smokers. Am J Med Genet B Neuropsychiatr Genet 2005; 132: 65-69.

99. Hanna GL, Veenstra-VanderWeele J, Cox NJ, Boehnke M, Himle JA, Curtis GC et al. Genome-wide linkage analysis of families with obsessive-compulsive disorder ascertained through pediatric probands. Am J Med Genet 2002; 114: 541-552.

100. Willour VL, Yao Shugart Y, Samuels J, Grados M, Cullen B, Bienvenu III OJ et al. Replication study supports evidence for linkage to 9 p24 in obsessive-compulsive disorder. Am J Hum Genet 2004; 75: 508-513.

101. Shugart YY, Samuels J, Willour VL, Grados MA, Greenberg BD, Knowles JA et al. Genomewide linkage scan for obsessive-compulsive disorder: evidence for susceptibility loci on chromosomes 3q, 7p, 1q, 15q, and 6q. Mol Psychiatry 2006; 11: 763-770.

102. Hovatta I, Tennant RS, Helton R, Marr RA, Singer O, Redwine JM et al. Glyoxalase 1 and glutathione reductase 1 regulate anxiety in mice. Nature 2005; 438: 662-666.

103. Buxbaum JD, Silverman J, Keddache M, Smith CJ, Hollander E, Ramoz N et al. Linkage analysis for autism in a subset families with obsessive-compulsive behaviors: evidence for an autism susceptibility gene on chromosome 1 and further support for susceptibility genes on chromosome 6 and 19. Mol Psychiatry 2004; 9: 144-150.
104. Kroes RA, Panksepp J, Burgdorf J, Otto NJ, Moskal JR. Modeling depression: socia dominance-submission gene expression patterns in rat neocortex. Neuroscience 2006 137: $37-49$.

105. Zhang S, Amstein T, Shen J, Brush FR, Gershenfeld HK. Molecular correlates of emotional learning using genetically selected rat lines. Genes Brain Behav 2005; 4 99-109.

106. Sarrazin N, Di Blasi F, Roullot-Lacarriere V, Rouge-Pont F, Le Roux A, Costet P et al. Transcriptional effects of glucocorticoid receptors in the dentate gyrus increase anxietyrelated behaviors. PLoS One 2009; 4: e7704.

107. Cole SW, Hawkley LC, Arevalo JM, Sung CY, Rose RM, Cacioppo JT. Social regulation of gene expression in human leukocytes. Genome Biol 2007; 8: R189.

108. Youngs RM, Chu MS, Meloni EG, Naydenov A, Carlezon Jr WA, Konradi C. Lithium administration to preadolescent rats causes long-lasting increases in anxiety-like behavior and has molecular consequences. J Neurosci 2006; 26 : $6031-6039$

109. Orsetti M, Di Brisco F, Rinaldi M, Dallorto D, Ghi P. Some molecular effectors of antidepressant action of quetiapine revealed by DNA microarray in the frontal cortex of anhedonic rats. Pharmacogenet Genomics 2009; 19: 600-612.

110. Grottick AJ, Bagnol D, Phillips S, McDonald J, Behan DP, Chalmers DT et al Neurotransmission- and cellular stress-related gene expression associated with prepulse inhibition in mice. Brain Res Mol Brain Res 2005; 139: 153-162.

111. Karssen AM, Her S, Li JZ, Patel PD, Meng F, Bunney Jr WE et al. Stress-induced changes in primate prefrontal profiles of gene expression. Mol Psychiatry 2007; 12 1089-1102.

112. Joo Y, Choi KM, Lee YH, Kim G, Lee DH, Roh GS et al. Chronic immobilization stress induces anxiety- and depression-like behaviors and decreases transthyretin in the mouse cortex. Neurosci Lett 2009; 461: 121-125.

113. Crowe RR, Goedken R, Samuelson S, Wilson R, Nelson J, Noyes Jr R. Genomewide survey of panic disorder. Am J Med Genet 2001; 105: 105-109.

114. Gelernter J, Page GP, Bonvicini K, Woods SW, Pauls DL, Kruger S. A chromosome 14 risk locus for simple phobia: results from a genomewide linkage scan. Mol Psychiatry 2003; 8: 71-82.

115. Cheng R, Juo SH, Loth JE, Nee J, lossifov I, Blumenthal R et al. Genome-wide linkage scan in a large bipolar disorder sample from the National Institute of Mental Health genetics initiative suggests putative loci for bipolar disorder, psychosis, suicide, and panic disorder. Mol Psychiatry 2006; 11: 252-260.

116. de Mooij-van Malsen AJ, van Lith HA, Oppelaar $H$, Hendriks $J$, de Wit $M$ Kostrzewa $\mathrm{E}$ et al. Interspecies trait genetics reveals association of Adcy8 with mouse avoidance behavior and a human mood disorder. Biol Psychiatry 2009; 66: 1123-1130.

117. Chen Q, Nakajima A, Meacham C, Tang YP. Elevated cholecystokininergic tone constitutes an important molecular/neuronal mechanism for the expression of anxiety in the mouse. Proc Natl Acad Sci USA 2006; 103: 3881-3886.

118. Sherrin T, Todorovic C, Zeyda T, Tan CH, Wong PT, Zhu YZ et al. Chronic stimulation of corticotropin-releasing factor receptor 1 enhances the anxiogenic response of the cholecystokinin system. Mol Psychiatry 2009; 14: 291-307.

119. Gratacos M, Costas J, de Cid R, Bayes M, Gonzalez JR, Baca-Garcia E et al. Identification of new putative susceptibility genes for several psychiatric disorders by association analysis of regulatory and non-synonymous SNPs of 306 genes involved in neurotransmission and neurodevelopment. Am J Med Genet B Neuropsychiatr Genet 2009; 150B: 808-816.

120. Hosing VG, Schirmacher A, Kuhlenbaumer G, Freitag C, Sand P, Schlesiger $C$ et al. Cholecystokinin- and cholecystokinin-B-receptor gene polymorphisms in panic disorder. J Neural Transm Suppl 2004; 68: 147-156.

121. Kennedy JL, Bradwejn J, Koszycki D, King N, Crowe R, Vincent $J$ et al. Investigation of cholecystokinin system genes in panic disorder. Mol Psychiatry 1999 4: $284-285$

122. Zohar AH, Dina C, Rosolio N, Osher $\mathrm{Y}$, Gritsenko I, Bachner-Melman R et al Tridimensional personality questionnaire trait of harm avoidance (anxiety proneness) is linked to a locus on chromosome 8p21. Am J Med Genet B Neuropsychiatr Genet 2003, 117B: 66-69.

123. Smoller JW, Acierno Jr JS, Rosenbaum JF, Biederman J, Pollack MH, Meminger S et al. Targeted genome screen of panic disorder and anxiety disorder proneness using homology to murine QTL regions. Am J Med Genet 2001; 105: 195-206.

124. Brocke B, Lesch KP, Armbruster D, Moser DA, Muller A, Strobel A et al. Stathmin, a gene regulating neural plasticity, affects fear and anxiety processing in humans. Am J Med Genet B Neuropsychiatr Genet 2010; 153B: 243-251.

125. Koenen KC, Amstadter AB, Ruggiero KJ, Acierno R, Galea S, Kilpatrick DG et al. RGS2 and generalized anxiety disorder in an epidemiologic sample of hurricane-exposed adults. Depress Anxiety 2009; 26: 309-315

126. Luciano M, Houlihan LM, Harris SE, Gow AJ, Hayward C, Starr JM et al. Association of existing and new candidate genes for anxiety, depression and personality traits in older people. Behav Genet 2010; 40: 518-532.

127. Logue MW, Durner M, Heiman GA, Hodge SE, Hamilton SP, Knowles JA et al. A linkage search for joint panic disorder/bipolar genes. Am J Med Genet B Neuropsychiatr Genet 2009; 150B: 1139-1146. 
128. Neylan TC, Sun B, Rempel H, Ross J, Lenoci M, O'Donovan A et al. Suppressed monocyte gene expression profile in men versus women with PTSD. Brain Behav Immun 2011; 25: 524-531.

129. Sherrin T, Blank T, Saravana R, Rayner M, Spiess J, Todorovic C. Region specific gene expression profile in mouse brain after chronic corticotropin releasing factor receptor 1 activation: the novel role for diazepam binding inhibitor in contextual fear conditioning Neuroscience 2009; 162: 14-22.

130. Cloninger CR, Van Eerdewegh P, Goate A, Edenberg HJ, Blangero J, Hesselbrock V et al. Anxiety proneness linked to epistatic loci in genome scan of human personality traits. Am J Med Genet 1998; 81: 313-317.
131. Kawai T, Morita K, Masuda K, Nishida K, Shikishima M, Ohta M et al. Gene expression signature in peripheral blood cells from medical students exposed to chronic psychological stress. Biol Psychol 2007; 76: 147-155.

(C)

Translational Psychiatry is an open-access journal published by Nature Publishing Group. This work is licensed under the Creative Commons Attribution-NoncommercialNo Derivative Works 3.0 Unported License. To view a copy of this license, visit http://creativecommons.org/licenses/by-nc-nd/3.0/

Supplementary Information accompanies the paper on the Translational Psychiatry website (http://www.nature.com/tp) 